\title{
Development of AM Technologies for Metals in the Sector of Medical Implants
}

\author{
Irene Buj-Corral $^{1, * \mathbb{D}}$, Aitor Tejo-Otero ${ }^{2}$ and Felip Fenollosa-Artés ${ }^{1,2} \mathbb{D}$ \\ 1 Departament of Mechanical Engineering, School of Engineering of Barcelona (ETSEIB), \\ Universitat Politècnica de Catalunya, Av. Diagonal, 647, 08028 Barcelona, Spain \\ 2 Centre CIM, Universitat Politècnica de Catalunya (CIM UPC), Carrer de Llorens i Artigas, 12, \\ 08028 Barcelona, Spain; atejo@cimupc.org (A.T.-O.); felip.fenollosa@upc.edu (F.F.-A.) \\ * Correspondence: irene.buj@upc.edu; Tel.: +34-934054015
}

Received: 9 April 2020; Accepted: 19 May 2020; Published: 23 May 2020

\begin{abstract}
Additive manufacturing (AM) processes have undergone significant progress in recent years, having been implemented in sectors as diverse as automotive, aerospace, electrical component manufacturing, etc. In the medical sector, different devices are printed, such as implants, surgical guides, scaffolds, tissue engineering, etc. Although nowadays some implants are made of plastics or ceramics, metals have been traditionally employed in their manufacture. However, metallic implants obtained by traditional methods such as machining have the drawbacks that they are manufactured in standard sizes, and that it is difficult to obtain porous structures that favor fixation of the prostheses by means of osseointegration. The present paper presents an overview of the use of AM technologies to manufacture metallic implants. First, the different technologies used for metals are presented, focusing on the main advantages and drawbacks of each one of them. Considered technologies are binder jetting (BJ), selective laser melting (SLM), electron beam melting (EBM), direct energy deposition (DED), and material extrusion by fused filament fabrication (FFF) with metal filled polymers. Then, different metals used in the medical sector are listed, and their properties are summarized, with the focus on $\mathrm{Ti}$ and $\mathrm{CoCr}$ alloys. They are divided into two groups, namely ferrous and non-ferrous alloys. Finally, the state-of-art about the manufacture of metallic implants with AM technologies is summarized. The present paper will help to explain the latest progress in the application of AM processes to the manufacture of implants.
\end{abstract}

Keywords: additive manufacturing; electron beam melting; selective laser melting; Ti-Al4-V6 alloy; $\mathrm{CoCr}$ alloys; implants; prostheses; biocompatibility

\section{Introduction}

Nowadays, industry is undergoing the 4th industrial revolution, which involves a lot of different fields such as nanotechnology, Internet of Things (IoT), and Artificial Intelligence (AI), among others. It also includes additive manufacturing (AM), which is the technology that builds 3D objects from successive layers. In recent years, the use of 3D printed parts in the medical sector has increased. According to the Wohlers report [1], the medical sector was the third most important one in the US in 2014 (Figure 1).

Additionally, the planet's population is increasing every year, along with life expectancy. It is therefore not difficult to imagine the different medical problems that can arise. For example, the appearance of new diseases or more people in need of surgery for organs transplantation as well as body parts' replacements such as knees or hips. 
According to the current technological development, it is possible to think about personalized medicine, for instance, the customization, design and fabrication of patient-particular products using AM technologies. Moreover, this technology could offer several significant advances:

- Creation of ideal products.

- $\quad$ Reduction of manufacturing times.

- Cost savings.

- Improvement in the strength of implants.

- Higher accuracy achievement.

- Production of lightweight implants.

- $\quad$ Surface quality excellence.

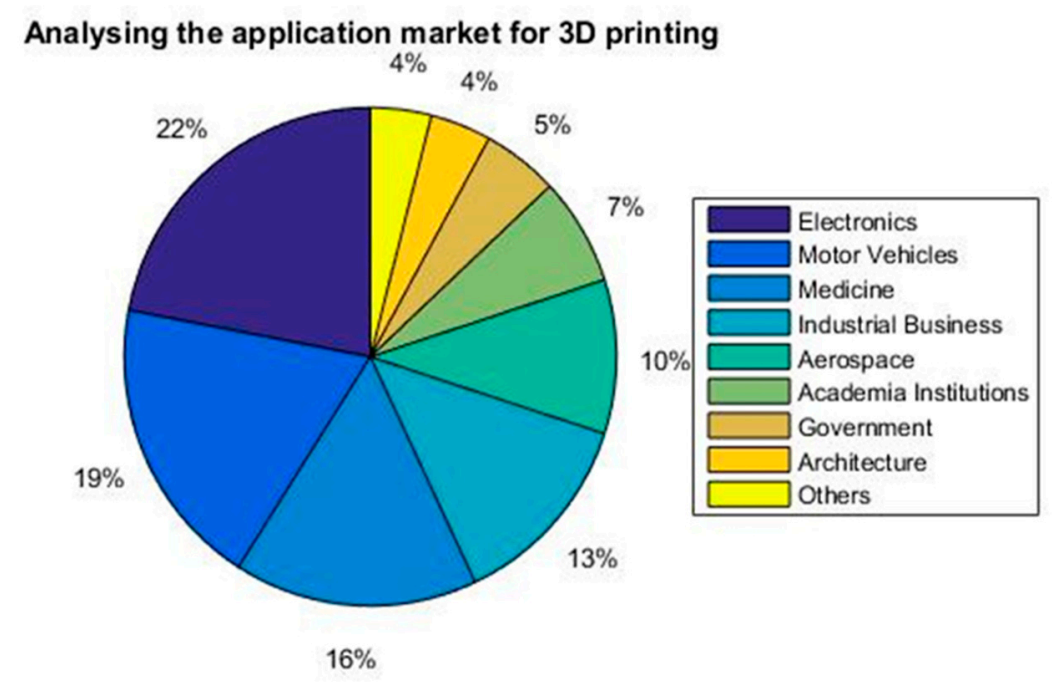

Figure 1. The distribution of additive manufacturing (AM) in different sectors [1].

Polymers are common in different medical applications such as tissue engineering [2], and the manufacture of surgical planning prototypes [3-7] and scaffolds [8]. Ceramic materials have also been employed in scaffolds [9]. However, in recent years the use of metals has increased in medicine. They can be found in several applications, such as surgical guides [10], prostheses [11], implants [12], etc. (Figure 2).

Most metallic parts used in the medical sector have complex shapes, in many cases combined with porous structures that favor their fixation in the body by means of osseointegration. AM can provide these shapes without excessively increasing costs. In addition, it allows customized parts to be produced from the DICOM (Digital Imaging and Communications in Medicine) files obtained, for example, in radiology tests.

The present paper focuses on the recent advances in AM of metallic implants, which are tissues or prostheses that are placed inside or on the surface of the body. Prostheses are artificially made parts of the body that replace a part that is missing, either internal or external.

First, the main AM technologies for metals are explained: binder jetting (BJ), selective laser melting (SLM), electron beam melting (EBM), direct energy deposition (DED), and fused filament fabrication (FFF). Next, the main properties of the metals that are used to manufacture prostheses and implants are summarized. Then, the recent advances regarding applications of AM metallic implants are presented. Finally, the main conclusions of the paper are summarized. 
(a)

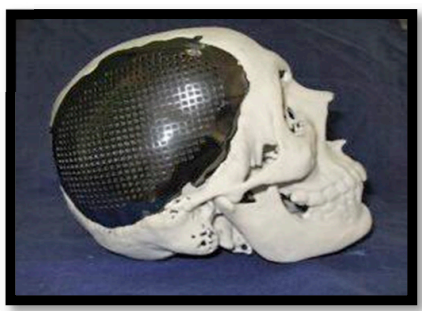

(b)

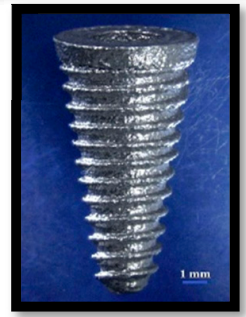

(c)

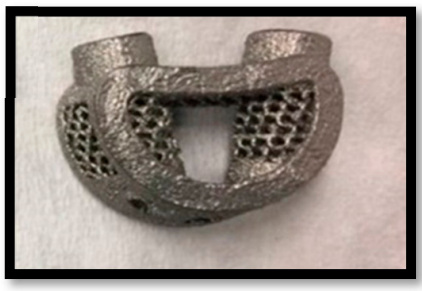

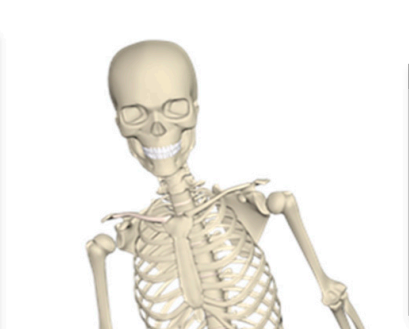

(d)

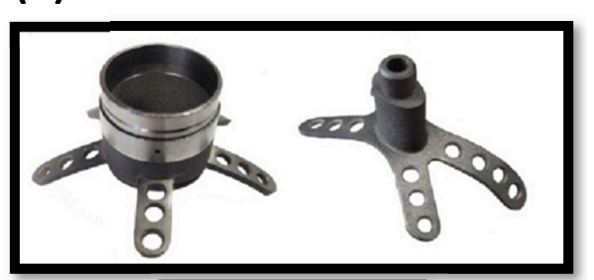

(e)

(f)

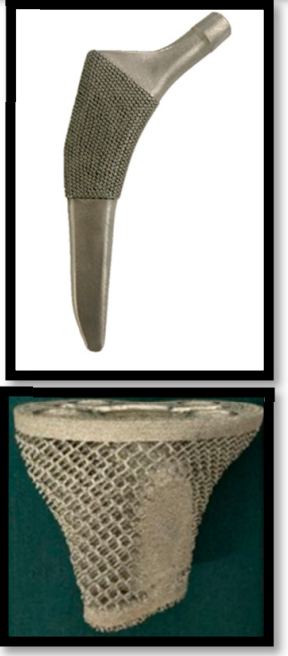

Figure 2. The medical applications of 3D printing of metals include the following: (a) cranial prostheses [13]; (b) dental implants [14]; (c) spinal cord implants [15]; (d) surgical guides [16]; (e) hip prostheses [17]; (f) interbody fusion cages. (a) Reprinted from Journal of Cranio-Maxillofacial Surgery, 42(8), A.L. Jardini, M.A. Larosa, R. M. Filho, C. A. de Carvalho Zavaglia, L. F. Bernardes, C. Salles Lambert, D. Reis Calderoni, P. Kharmandayan, Cranial reconstruction: 3D biomodel and custom-built implant created using additive manufacturing, 1877-1884, Copyright (2014), with permission from Elsevier. (b) Reprinted from The Journal of Prosthetic Dentistry, 112(5), J. Chen, Zh. Zhang, X. Chen, Ch. Zhang, G. Zhang, Zh. Xu, Design and manufacture of customized dental implants by using reverse engineering and selective laser melting technology, 1088-1095, Copyright (2014), with permission from Elsevier. (c) Reprinted from World Neurosurgery, 105, W. J. Choy, R. J. Mobbs, B. Wilcox, S. Phan, K. Phan, Ch. E. Sutterlin, Reconstruction of Thoracic Spine Using a Personalized 3D-Printed Vertebral Body in Adolescent with T9 Primary Bone Tumor, 1032.e13-1032.e17, Copyright (2017), with permission from Elsevier. (d) Reprinted from Journal of Neuroscience Methods, 286, X. Chen, J. K. Possel, C. Wacongne, A.F. van Ham, P. Ch. Klink, P.R. Roelfsema, 3D printing and modelling of customized implants and surgical guides for non-human primates, 38-55, Copyright (2017), with permission from Elsevier. (e) Reprinted from Journal of Orthopaedic Research, 15(8), S. Arabnejad, B. Johnston, M. Tanzer and D. Pasini. Fully porous 3D printed titanium femoral stem to reduce stress-shielding following total hip arthroplasty, 10, Copyright (2016), with permission from John Wiley and Sons. (f) Reprinted from Medical Science Monitor, 23, W. Luo, L. Huang, B. H. Liu, W. Qu, X. Zhao, Ch. Wang, Ch. Li, T. Yu, Q. Han, J. Wang, and Y. Qin, Customized Knee Prosthesis in Treatment of Giant Cell Tumors of the Proximal Tibia: Application of 3-Dimensional Printing Technology in Surgical Design., 1691-1700, Copyright (2017), with permission from ISL Publisher.

\section{AM Technology Processes for Metals}

According to the ASTM F2792-12a [18] standard, from ASTM International, West Conshohocken, PA, US, additive manufacturing (AM) technologies can be classified into seven different groups: binder jetting, directed energy deposition, material extrusion, material jetting, powder bed fusion, sheet lamination, and vat photopolymerization. Among the procedures that allow metals to be processed, the following can be highlighted: binder jetting, powder bed fusion-which includes selective laser 
melting (SLM) and electron beam melting (EBM)—direct energy deposition (DED), and material extrusion by fused filament fabrication (FFF) with metal filled polymers.

\subsection{Binder Jetting (BJ)}

Binder jetting (BJ) is an AM technology process in which a liquid binding agent is selectively deposited onto the layer of materials (in the form of powder) in order to bind the particles. First, a layer of powder material is spread uniformly across the platform. Then, the binder droplets are dispensed onto the layer by using an inkjet printing head that is moved along the $\mathrm{X}$ - and Y-axis to selectively distribute the binder through a nozzle. Then, the binder bonds the powder particles and the build platform lowers in $Z$ direction for a small distance, in order to repeat the process again [19]. The binding agent for metals is usually a polymeric adhesive. Finally, once the part is 3D-printed (known as green part), it is separated from the 3D printing machine, and excess powder is removed with pressurized air. The parts are in "green state", with low mechanical properties and with high porosity. Improving the final density of the parts requires a finishing treatment such as sintering or infiltration. In the sintering process, the parts are placed into a high temperature furnace, eliminating the binding agent and consolidating the metallic internal structure by a partial fusion process of the metallic powder. However, sintering causes material shrinkage. Infiltration consists of heating the part in a furnace at a lower temperature. Then, an alloy such as bronze infiltrates the voids by capillary action [20]. As a general trend, infiltration leads to higher density than sintering [21]. Hot isostatic pressing can provide pressure to the sintering operation, thus increasing the final density of the parts [22].

An example of a machine using this technology is the Studio System of Desktop Metal, Burlingtion, MA, US. It has the following characteristics: speed up to $12,000 \mathrm{~cm}^{3} / \mathrm{h}$, build volume of $490 \times 380 \times 260 \mathrm{~mm}^{3}$, and a resolution of $\leq 50 \mu \mathrm{m}$ voxels. Additionally, it has a bi-directional printing system [23].

The main advantages and disadvantages of metallic binder jetting can be seen in Table 1 .

Table 1. Advantages and disadvantages of binder jetting [24-26].

\begin{tabular}{cc}
\hline Advantages & Disadvantages \\
\hline $\begin{array}{c}\text { No need to design nor use supports } \\
\text { Unused powder can be reused } \\
\text { Wide range of materials } \\
\text { Fast process }\end{array}$ & Limited success in producing metallic parts \\
Large build size & Wow density \\
\hline
\end{tabular}

Although this technique is mainly used for ceramic materials, for example to obtain sand molds and cores in the sand casting process [27], it is also employed for metal matrices [28]. For example, iron parts with enhanced strength are obtained by means of bronze infiltration [29]. However, the high density of metals makes them less stable than other materials, and the fine particles can be prone to oxidation [26]. Different materials such as titanium [30], stainless steel [20], CoCr alloys [31], or Inconel [21] have been manufactured with binder jetting. In addition, since this technology does not require the use of an energy beam for processing metals, it is a good choice for reflective and thermally conductive metals, which can be challenging to be processed by powder bed fusion technologies [32].

\subsection{Powder Bed Fusion by Selective Laser Melting (SLM)}

Powder bed fusion by selective laser melting (SLM) using metallic powder is an AM process that is similar to selective laser sintering (SLS). Unlike SLS, in which the particles are only sintered, the SLM technique uses a high power-density laser in order to melt and fuse the metallic powders together. Other common names for this powder bed fusion technology for metals are DMLS (direct metal laser sintering) and DMP (direct metal printing). 
The process starts by the spreading of a thin layer of the metal powder. Then, a high power-density laser is used in order to melt and fuse the metallic powders together. After this, the build platform is lowered in the $\mathrm{Z}$ direction and the process is repeated again until the 3D printed required part is built. SLM takes place in a chamber with inert gas atmosphere, using, for instance, argon or nitrogen.

Two examples of machines using this technology are the SLM 125 and SLM 2802.0 of SLM Solutions Group AG, Lübeck, Germany [33]. On the one hand, SLM 125 has a build volume of $125 \times 125 \times 125 \mathrm{~mm}^{3}$ and a printing speed of $25 \mathrm{~cm}^{3} / \mathrm{h}$. On the other hand, SLM 2802.0 has a build volume of $280 \times 280 \times 365 \mathrm{~mm}^{3}$ and a printing speed of $113 \mathrm{~cm}^{3} / \mathrm{h}$. These latter values depend on the materials and part geometry.

The main advantages and disadvantages of SLM can be seen in Table 2.

Table 2. Advantages and disadvantages of SLM [34-40].

\begin{tabular}{cc}
\hline Advantages & Disadvantages \\
\hline $\begin{array}{c}\text { Medium productivity } \\
\text { Very complex shapes (thin walls, hidden holes, } \\
\text { porous structures) } \\
\text { Excellent mechanical properties of the 3D object } \\
\text { Good repeatability }\end{array}$ & $\begin{array}{c}\text { High price } \\
\text { Corrosion sensitive }\end{array}$ \\
Medium to high surface quality & $\begin{array}{c}\text { Lower scan speed than EBM } \\
\text { It requires build structures because of the weight of } \\
\text { the metallic parts and distortion at high temperature }\end{array}$ \\
\hline
\end{tabular}

Although ideal materials are pure metals, different alloys can also be used in the SLM process, such as stainless steel, CoCr alloys, titanium alloys, and aluminum [41].

\subsection{Powder Bed Fusion by Electron Beam Melting (EBM)}

Powder bed fusion by electron beam melting (EBM) is a type of 3D printing process for metals in which the object material, normally in the form of powder, is manufactured by melting layer-by-layer with an electron beam at high temperature in a high vacuum atmosphere.

Firstly, a layer of metal powder is distributed onto the build platform, and melted by the electron beam. Then, the build platform is lowered, and another layer of metal powder is subsequently coated on top.

One example of a machine of this technology is the Arcam EBM Q20plus, from GE Additive, Boston, MA, USA [42]. It has an electron beam power of $3 \mathrm{~kW}$ and a build volume of $350 \mathrm{~mm}$ in diameter and 380 in heigtt. Additionally, EBM takes place in a vacuum and at high temperatures.

The main advantages and disadvantages of EBM can be seen in Table 3.

Table 3. Advantages and disadvantages of EBM [41,43].

\begin{tabular}{cc}
\hline \multicolumn{1}{c}{ Advantages } & Disadvantages \\
\hline Possibility of working at elevated temperatures & High fatigue \\
Better protection against contamination & Danger for electrostatic charge of the powder \\
Low level of residual stresses & Only conductive alloys can be obtained \\
Absence of shrinkage, no thermal post-processing & $\begin{array}{c}\text { Rough finish that requires polishing (depending on } \\
\text { process conditions) } \\
\text { Allows stacking parts and obtaining meshes }\end{array}$ \\
\hline
\end{tabular}

Titanium alloys, CoCr alloys, stainless steel and Inconel are frequently employed in EBM processes [41].

\subsection{Direct Energy Deposition (DED)}

Direct energy deposition (DED) is an additive manufacturing process in which an energy source such as an electron, laser beam or electric arc, is aimed at the material (in the form of powder or wire), 
in order to fuse the materials by melting while they are being deposited. Due to the use of four-or five-axis machines, the material can be deposited from any angle onto the existing surfaces of the object and then melted. The process requires a chamber with inert gas to control the material properties and to avoid oxidation of the material.

Two examples of machines using this technology are the INTEGREX i-400 AM and the DMD 503D/505D, from Yamazaki Mazak Corporation, Oguchi, Japan. On the one hand, INTEGREX i-400 $\mathrm{AM}$ is a five-axis multi-tasking machine and it is used for 3D printing of materials which are difficult to be machined [44]. On the other hand, DMD 503D/505D has a build volume of $1590 \times 1400 \times 1470$ $\mathrm{mm}^{3}$ and a position accuracy of $0.03 \mathrm{~mm}$ [45].

The advantages and disadvantages of DED can be seen in Table 4.

Table 4. Advantages and disadvantages of DED [46-49].

\begin{tabular}{cc}
\hline Advantages & Disadvantages \\
\hline Low waste of material & Low build resolution \\
No supports are needed & Poor surface finish \\
Rapid material deposition & Support structures can not be used, thus overhangs \\
Allows hybrid machines & can not be obtained \\
& Machines are expensive \\
\hline
\end{tabular}

A wide range of metals can be used, including titanium alloys, stainless steel, aluminum alloys, tantalum, tungsten, niobium, Inconel, nickel copper, etc. [47].

\subsection{Material Extrusion by Fused Deposition Modelling (FDM) or Fused Filament Fabrication (FFF)}

In the FFF or FDM technique, a filament is melted, extruded through a nozzle and subsequently deposited on a printing bed layer-by-layer. Once a layer it deposited, the build platform is lowered (in low-cost machines, the build platform does not lower after each layer is deposited). Finally, when the piece is completed, it is placed into a sintering furnace to remove the plastic and sinter the metal particle together. Both debinding and sintering processes are required after extrusion, which cause material shrinkage.

One example of a machine of this technology is the Metal X of Markforged, Watertown, MA, USA. It has a build volume of $300 \times 220 \times 180 \mathrm{~mm}^{3}$ and a $\mathrm{Z}$ resolution of between 50 and $125 \mu \mathrm{m}$ [50].

The main advantages and disadvantages of FFF can be seen in Table 5 .

Table 5. Advantages and disadvantages of FFF with high metallic content [51-53].

\begin{tabular}{cc}
\hline Advantages & Disadvantages \\
\hline $\begin{array}{c}\text { Simple technology } \\
\text { Wide range of materials }\end{array}$ & Low accuracy \\
$\begin{array}{c}\text { Possibility to use low cost machines } \\
\text { Reliable }\end{array}$ & Shear stress on nozzle tip wall \\
& Bad resolution \\
& Poor mechanical properties, although enhanced with respect to polymers \\
& Thermal postprocess (associated with shrinkage)
\end{tabular}

Although it is associated with plastic materials such as polylactic acid (PLA) or acrylonitrile butadiene styrene (ABS), the filament can be filled with a high percentage of metallic particles in order to print metallic parts. Some of the metals used are copper [54], stainless steel [55], and titanium [56].

\subsection{Comparison of the AM Technology Process for Metals}

Before any object is 3D printed several factors must be considered. In other words, depending on the objective of the product, the material used, etc., it might be better to use one technology or another. Therefore, it is important to compare different aspects of the AM technologies (Table 6). 
Table 6. Comparison of the AM technology process for metals.

\begin{tabular}{ccccccc}
\hline Characteristic & BJ & SLM & EBM & DED & FFF & References \\
\hline Parts complexity & Average & Complex & Average & Simple & Simple & {$[37,57-59]$} \\
Resolution & High & High & Average & Low & Low & {$[59]$} \\
Productivity & High & High & Average & Low & Low & {$[37,59,60]$} \\
Surface finish & High & Average & Average & Poor & Poor & {$[43,61,62]$} \\
Mechanical & Average & High & Average & Average & Poor & {$[40,62-68]$} \\
properties & Fast & Low & Average & Average & Average & {$[40]$} \\
Printing speed & High & Minimal & Average & High & Minimal & {$[37,62,65,69,70]$} \\
Porosity & Low & High & High & High & Low & {$[37,40,71,72]$} \\
Accuracy & Low & High & High & Average & Average & {$[26,37,73-75]$} \\
Corrosion resistance & & & & & &
\end{tabular}

Regarding the manufacturing costs, the following values are the printing costs per unit [76]: (1) \$ 2.50-4 for laser powder bed, (2) \$ 1.33-3 for e-beam powder bead, (3) \$ 0.33-1.5 for powder DED, (4) \$ 0.25-0.6 for wire DED, and (5) \$ 0.08-1.5 for binder jetting. Thus, among the studied processes, the most expensive one is laser powder bed (SLM) followed by e-beam powder bed (EBM).

\section{Metals Used in the Medical Sector}

Different metals and alloys are currently used in the medical sector. They can be divided into two categories: ferrous and non-ferrous (Figure 3).

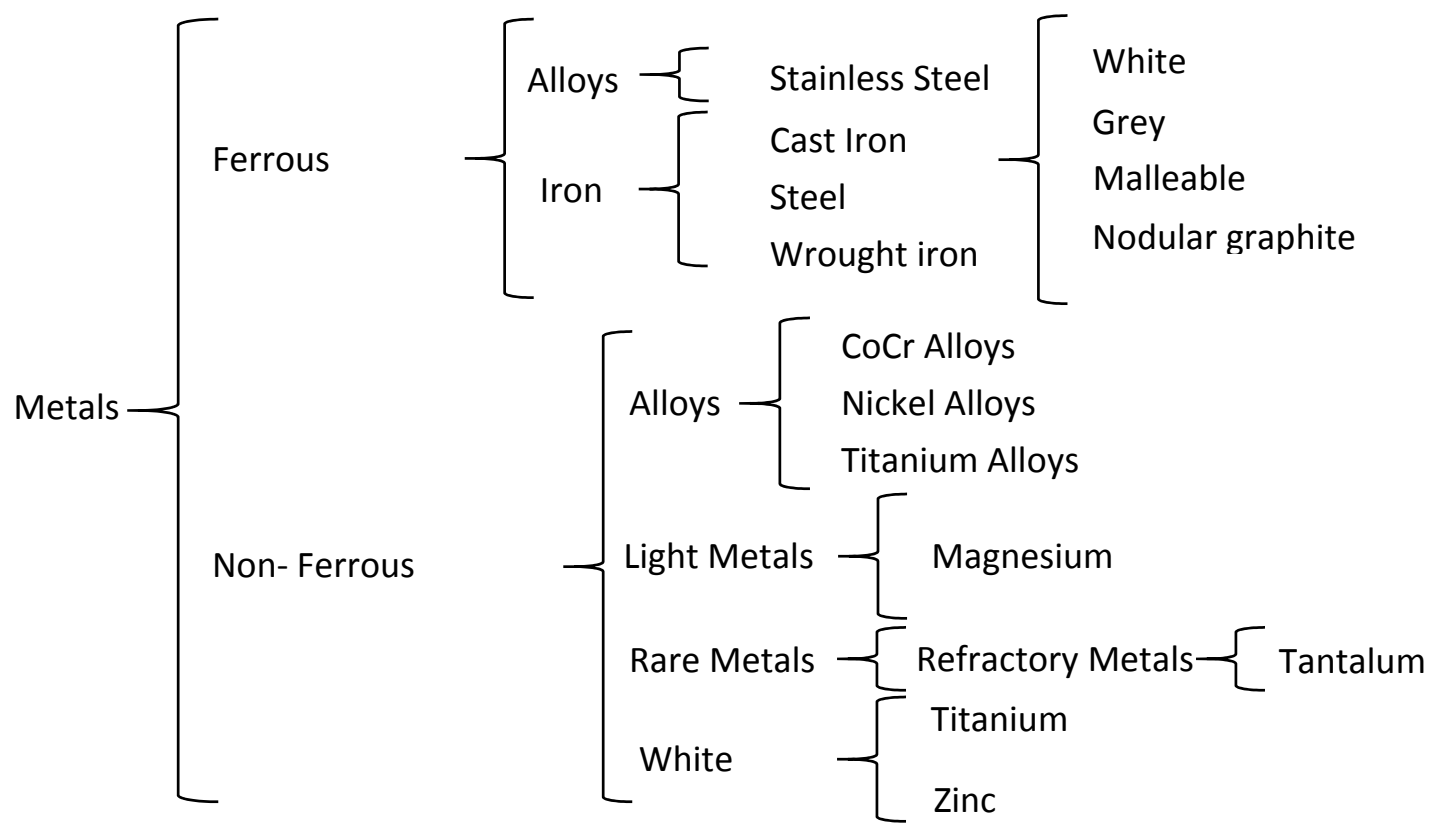

Figure 3. Metals classification in the medical sector.

Ideally, an alloy used for implants should be biocompatible and have good mechanical properties, i.e., high tensile, compressive and shear strength, high fatigue strength to prevent failure under cyclic loading, and low elastic modulus comparable to that of bone. They should also have high corrosion resistance, high wear resistance, and a low price. Another important factor to be considered is the possibility to obtain porous structures, because they influence both the mechanical strength and the biological properties of the tissues. On the other hand, the osseointegration of bones depends on both biomechanical interlocking and biological interactions, which are related to the surface roughness of the implants. These properties are in more depth in Section 4.10.

Among the ferrous alloys, the most frequently employed one to manufacture implants is stainless steel due to its high corrosion resistance. However, it has low fatigue strength and undergoes 
deformation. Consequently, it is mainly used for non-permanent implants. Regarding the non-ferrous materials, some of them are bio tolerant like CoCr alloys, gold, niobium and tantalum, while pure titanium and titanium alloys are bio inert [77]. Ion release is one of the main disadvantages of $\mathrm{CoCr}$ alloys, titanium, and titanium alloys, although they provide high corrosion resistance. In addition, differences in mechanical properties between the bone and the implant can lead to stress shielding problems, with either a loosening of implants or the growth of soft fibrous tissue [78].

Figure 4 provides a comparison of metals by focusing only on the material price. This does not include the manufacturing costs, and prices are related to the market price. According to their price, metals can be divided into three categories. The green area corresponds to the cheap ones, the yellow area to the medium ones, and the red area to the expensive ones, in this case tantalum, with a price above $110 € / \mathrm{kg}$.

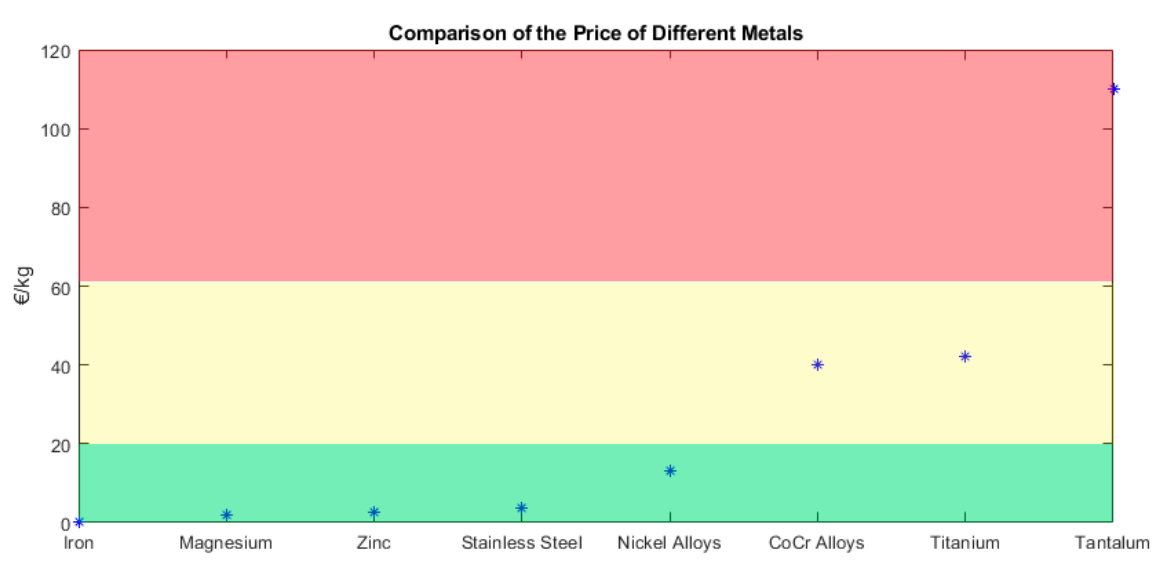

Figure 4. Classification of metals according to their price [79].

The manufacturing costs can be divided into two groups: fixed and recurring [62]. On the one hand, the fixed costs correspond to the manufacturing tools, dies, machines, etc. These costs are amortized over time and, therefore, the more the 3D printing machines are used, the lower the costs per printed piece are. On the other hand, the recurring costs include the material price and labor. Regarding the materials, it is important that they are easily 3D printed and have good physical and mechanical properties, but without excessive cost.

The following paragraphs present the main characteristics of the metals that are employed to manufacture metallic implants by means of AM processes.

\subsection{Ferrous}

A ferrous metal contains iron in its composition, as well as carbon. They can be divided into two categories, namely (a) alloys such as stainless steel and (b) iron.

\subsubsection{Stainless Steel}

It is an iron alloy containing at least $10.5 \%$ of chromium and $1.2 \%$ of carbon. Chromium offers the stainless steel the benefit of being resistant to corrosion thanks to the chromium oxide layer, unlike the regular steel. Additionally, stainless steel can have other materials but in lower proportions such as molybdenum or nickel [80]. Some examples of stainless steel are SAE 304, SAE 316 and SAE 316L Boron-titanium modified stainless steel, defined by the Society of Automotive Engineers (SAE). SAE $316 \mathrm{~L}$ has been used in recent years for biomedical applications. Sintering of the material in a nitrogen atmosphere helps to retain the nickel ions in the stainless steel [81], which would otherwise be released from implants due to local corrosion [82]. Additionally, it is necessary to carry out cell culture studies, such as cytotoxicity assays or cells imaging [83], to verify its biocompatibility. As 
for SLM manufactured stainless steel, biocompatibility increases when the material is coated with hydroxyapatite [84].

The main advantages and disadvantages of stainless steel can be seen in Table 7.

Table 7. Advantages and disadvantages of stainless steel $[80,85]$.

\begin{tabular}{cc}
\hline Advantages & Disadvantages \\
\hline High corrosion resistance & Sometimes difficult to handle \\
Heat resistance & Release of chromium and nickel \\
Biocompatible & Prone to deformation \\
Excellent mechanical properties & Low fatigue strength when subjected to oxidation \\
Easy fabrication & \\
Non-porous & \\
\hline
\end{tabular}

3.1.2. Iron

It is only the most common element on Earth by mass, and also in the human body. It can be classified into three categories depending on the carbon content: wrought iron (less than $0.08 \% \mathrm{C}$ ), carbon steel (between 0.08 and $1.76 \% \mathrm{C}$ ) or cast iron (more than $1.76 \% \mathrm{C}$ ). Additionally, cast iron can be divided into smaller groups such as white, grey, malleable and nodular graphite.

The advantages and disadvantages of wrought iron can be seen in Table 8.

Table 8. Advantages and disadvantages of wrought iron [86].

\begin{tabular}{cc}
\hline Advantages & Disadvantages \\
\hline Tough & Cannot be hardened \\
Excellent mechanical properties & Sometimes difficult to handle \\
Corrosion resistance & High cost \\
Excellent weldability & \\
\hline
\end{tabular}

Weldability is an important factor to be taken into consideration when a part needs to be joined to another of either a similar or dissimilar material [87], e.g., in implants. If cracks are easily avoided, the materials are 'weldable'.

Fe-Mn alloy has been used to produce bone scaffolds by SLM [88]. Mn is added to control the high degradation of Fe. Moreover, in another study, a Fe-HA (iron-hydroxyapatite) composite was manufactured using different particles sizes [89]. Not only were better corrosion rates obtained than for pure iron, but also with the addition of HA closer mechanical properties to those of bone are also obtained. For example, pure iron tensile strength is $215 \mathrm{MPa}$, for Fe $+2.5 \mathrm{wt} \% \mathrm{HA}(1-10 \mu \mathrm{m})$ it is $117 \mathrm{MPa}$ and the strength of the human femur bone is $135 \mathrm{MPa}$ (longitudinal tension) [90].

The advantages and disadvantages of carbon steel can be seen in Table 9.

Table 9. Advantages and disadvantages of carbon steel [86].

\begin{tabular}{cc}
\hline Advantages & Disadvantages \\
\hline Excellent mechanical properties & Ductility decreases with carbon content \\
Good weldability & Susceptible to rust and corrosion \\
Good formability & \\
Hard and tough & \\
Low stress concentration & \\
Resistant to oxidation & \\
\hline
\end{tabular}

The main advantages and disadvantages of cast iron can be seen in Table 10. 
Table 10. Advantages and disadvantages of cast iron [86].

\begin{tabular}{cc}
\hline Advantages & Disadvantages \\
\hline Excellent mechanical properties & High brittleness \\
Biocompatible & Low machinability \\
Cytocompatibility & \\
Good castability & \\
Low stress concentration & \\
Resistant to oxidation & \\
\hline
\end{tabular}

Machinability is measured by focusing in the machinability index. The value of 100 is the average, with carbon steel 1212 being the average. Therefore, a value lower than 100 means that the machinability is more difficult and, therefore, the production time is lower; while with a value higher than 100 it is easier. In terms of cast iron, it ranges from 36 to 78 [91].

\subsection{Non-Ferrous}

Non-ferrous metals do not contain iron in appreciable amounts and are generally more costly than ferrous metals due to their desirable properties. They can be divided into different categories: (a) alloys, (b) light metals, (c) rare metals, and (d) white.

\subsubsection{CoCr Alloys}

Cobalt-chromium alloys are alloys composed mainly of cobalt and chromium. They are used in aerospace engineering amongst other applications. However, taking into account their excellent properties, they have been used in dentistry for decades [85]. Most employed $\mathrm{CoCr}$ alloys in medical applications are $\mathrm{Co}-\mathrm{Cr}-\mathrm{Mo}, \mathrm{Co}-\mathrm{Ni}-\mathrm{Cr}-\mathrm{Mo}$, and $\mathrm{Co}-\mathrm{Cr}-\mathrm{W}-\mathrm{Ni}$ [92]. Using this metal alloy has a major drawback, which is the ion release, which could lead to adverse effects such as toxicity, metallic taste, mucosities, etc.

The advantages and disadvantages of the CoCr alloys can be seen in Table 11.

Table 11. Advantages and disadvantages of the CoCr alloys [68,92].

\begin{tabular}{cc}
\hline Advantages & Disadvantages \\
\hline Excellent mechanical properties & Wear and corrosion can lead to the release of metal ions \\
Excellent corrosion resistance & High cost \\
Biocompatibility & Limitations on component complexity \\
\hline
\end{tabular}

\subsubsection{Nickel Alloys}

Nickel (Ni) alloys are metals made from a combination of nickel as the primary element and another material such as $\mathrm{Ni}-\mathrm{Al}$ alloy, $\mathrm{Ni}-\mathrm{Cr}$ alloy or Ni-Ti alloy. Although nickel is very toxic, a titanium oxide layer is formed that prevents from nickel oxidation [92]. An example of Ni-Ti alloy is Nitinol, which contains approximately $50 \%$ of $\mathrm{Ni}$ and $50 \%$ of Ti. Nitinol is a shape memory alloy, which retains its original shape after severe deformations. It is used for hard tissue implants and in dentistry. In recent years, the behavior of SLM printed Ni-Ti alloys has been addressed [93,94].

The advantages and disadvantages of the nickel alloys can be seen in Table 12. The low thermal conductivity of nickel complicates its manufacture; for example, in machining or high temperature AM processes, because heat cannot be easily removed from the working area, thus increasing working temperatures. 
Table 12. Advantages and disadvantages of the nickel alloys [92,95].

\begin{tabular}{cc}
\hline Advantages & Disadvantages \\
\hline Heat resistance & Low thermal conductivity \\
Corrosion resistance & High price \\
Low-expansion & Difficult to machine \\
Shape memory & \\
Magnetic permeability & \\
\hline
\end{tabular}

\subsubsection{Titanium}

Titanium (Ti) is the ninth-most abundant chemical element in the Earth's crust and it can be combined with other elements in order to form the known titanium alloys. It is widely used in several applications such as dental implants, but during the last few years, it has assumed greater importance in the biomedical applications such as hip prostheses, especially due to its biocompatibility and high fracture resistance. These two parameters are important in prostheses for two reasons: (1) biocompatibility so that the host tissue does not reject the implant: (2) high fracture resistance so that the implant does not fracture. Commercial pure titanium (CP-Ti) has an excellent biocompatibility because of a stable oxide layer that forms spontaneously on its surface [96].

Regarding the use of SLM, Taniguchi et al. [97] investigated the bone ingrowth of different pore sizes of titanium implants manufactured by SLM. Finding the best titanium implant for osseointegration is essential, so that the implant integrates as quickly as possible with the bone.

The advantages and disadvantages of the titanium can be seen in Table 13.

Table 13. Advantages and disadvantages of the titanium [98,99].

\begin{tabular}{cc}
\hline Advantages & Disadvantages \\
\hline Strength-to-density ratio & Difficult to process \\
Corrosion resistance & Unstable creep \\
Light-weight & Low elastic modulus \\
Strength & Wear debris causes biological reactions \\
Biocompatible & \\
\hline
\end{tabular}

\subsubsection{Titanium Alloys}

Titanium alloys contain titanium and other chemical elements. Different alloys are used in medical applications, such as $\alpha+\beta$ alloys, Ti-Al- $\mathrm{Nb}$ and $\beta$-Ti alloy [92]. However, the most typical example is Ti- $6 \mathrm{Al}-4 \mathrm{~V}$ which is an $\alpha-\beta$ titanium alloy containing a $6 \%$ aluminum and $4 \%$ vanadium. A specific alloy Ti6Al4V ELI (extra-low interstitial) alloy provides higher ductility and fracture toughness than the conventional alloy [100].

The three most developed techniques for additively manufacturing titanium alloy structures are direct energy deposition (DED), selective laser melting (SLM) and electron beam melting (EBM) $[65,101]$. For example, porous parts implants can be manufactured using SLM technology and they can achieve a mimicking of the human bone at a $60 \%$ of porosity [102].

The advantages and disadvantages of the titanium alloys can be seen in Table 14 .

Table 14. Advantages and disadvantages of the titanium alloys $[65,103]$.

\begin{tabular}{cc}
\hline Advantages & Disadvantages \\
\hline Excellent biocompatibility & Stress shielding \\
Corrosion resistance & High price \\
High ratio strength & Low elastic modulus \\
High temperature strength & Poor tribological properties \\
Good creep resistance & \\
\hline
\end{tabular}


Other titanium alloys, such as Ti-6Al-7Nb [104,105], have been used for printing implants as well as others such as Ti-24Nb-4Zr-8Sn [106] or Ti-33Nb-4Sn [107]. A typical niobium alloy used for prostheses is $\mathrm{Ti}-42 \mathrm{Nb}$.

\subsubsection{Magnesium}

Magnesium $(\mathrm{Mg})$ is a light material with a relatively high mechanical strength that can replace aluminum in some applications. However, its accelerated corrosion rate in physiological environments reduces its potential use in implants [108]. Nevertheless, magnesium-based biodegradable materials are promising candidates, making a second surgery for implant removal unnecessary $[109,110]$. Magnesium powder is flammable and should be handled with care [111].

The main advantages and disadvantages of magnesium can be seen in Table 15.

Table 15. Advantages and disadvantages of magnesium [85,108,111,112].

\begin{tabular}{cc}
\hline Advantages & Disadvantages \\
\hline Low density & Flammable \\
Good machinability & Poor corrosion resistance \\
Light-weight & High cost \\
Excellent in vivo compatibility & Low elastic modulus \\
Fully bioresorbable & Moderate strength \\
\hline
\end{tabular}

Magnesium scaffolds have been prepared with the purpose of bone regeneration [113].

\subsubsection{Tantalum}

Tantalum (Ta) is a very chemically resistant metal and, consequently, it is widely used in biomedical applications. Additionally, it is inert to practically all the organic and inorganic compounds. Tantalum has been printed with the SLM technique [114].

The main advantages and disadvantages of the tantalum alloys can be seen in Table 16 .

Table 16. Advantages and disadvantages of the tantalum $[115,116]$.

\begin{tabular}{cc}
\hline Advantages & Disadvantages \\
\hline Excellent biocompatibility & High manufacturing costs \\
Good chemical stability & High melting point \\
Excellent osseointegration & \\
Good corrosion resistance & \\
With designed porosity, similar elastic modulus to \\
that of bone
\end{tabular}

\subsubsection{Zinc}

Zinc $(\mathrm{Zn})$ is one of the most indispensable trace elements in the human body and it is often employed in industry for the surface treatment of steel, for example in galvanization or electroplating processes. In medical applications, it has been used in cardiovascular stents and dental implants, amongst others.

The strength of zinc can be improved by alloying with elements such as $\mathrm{Mg}, \mathrm{Ca}, \mathrm{Sr}, \mathrm{Li}$, and $\mathrm{Cu}$ [117]. On the other hand, inorganic $\mathrm{Zn}$ compounds such as Zn-hydroxyapatite [118] or ZnO [119] can be used to manufacture implants.

The main advantages and disadvantages of zinc can be seen in Table 17. 
Table 17. Advantages and disadvantages of zinc [117].

\begin{tabular}{cc}
\hline Advantages & Disadvantages \\
\hline Accuracy & Low toughness \\
High impact strength & Brittle \\
Durable & \\
Cost-effective & \\
Fully bioresorbable & \\
Good biocompatibility & \\
\hline
\end{tabular}

\subsubsection{Other Metals and Alloys}

There are other metals that are not as commonly used in the medical sector, except in a few biomedical applications. For instance, copper $(\mathrm{Cu})$ is the third most important trace element in the human body. Some commercially available copper alloys are $\mathrm{Cu}-\mathrm{Al}-\mathrm{Ni}$ and $\mathrm{Cu}-\mathrm{Al}-\mathrm{Mn}$ [92]. However, it has been proved that it is both difficult and expensive to print copper [120].

Pure Tungsten (W) powder has also been used in SLM processes [121], as well as pure Niobium $(\mathrm{Nb})$ [122]. Neodymium $(\mathrm{Nd})$ has been added to the Mg-5Zn-0.35Zr-0.13Y, improving the mechanical strength and corrosion resistance of the alloy [108].

Although aluminum is not a suitable material for implants because of its easy oxidation, it is found in many titanium alloys like Ti-6Al-4V [85].

Gold alloys were used in the past for dental implants [92]. However, they are not commonly used nowadays because of their high price.

\subsubsection{Comparison of the Metals}

A comparison of the different metals was made, regarding their most important properties (Table 18). 
Table 18. Comparison of the metals and alloys used for implants.

\begin{tabular}{|c|c|c|c|c|c|c|c|c|c|}
\hline Characteristics & SS & Iron & CoCr Alloys & $\begin{array}{c}\text { Ni } \\
\text { Alloys }\end{array}$ & $\begin{array}{c}\mathrm{Ti} \\
\text { Alloys }\end{array}$ & $\mathrm{Mg}$ & Ta & $\mathrm{Zn}$ & References \\
\hline Melting Point $\left({ }^{\circ} \mathrm{C}\right)$ & $1325-1500$ & $1150-1600$ & $\approx 1600$ & $\approx 1450$ & 1670 & 650 & 2980 & 420 & [123] \\
\hline Yield Strength (MPa) & $\approx 250$ & 130 & $480-580$ & $\approx 600$ & $\approx 750$ & $\approx 150$ & $\approx 230$ & $50-120$ & [124-128] \\
\hline Tensile Strength (MPa) & 450 & 350 & $\approx 800$ & $\approx 1000$ & $\approx 900$ & $\approx 250$ & $\approx 260$ & $100-200$ & {$[124,126,128,129]$} \\
\hline Elastic Modulus (GPa) & 200 & 200 & $\geq 150$ & $\approx 150$ & 120 & $\approx 40$ & $\approx 185$ & $\approx 100$ & [124] \\
\hline Vickers hardness (HV) & 275 & $30-80$ & $380-430$ & 300 & 350 & 100 & $\approx 1000$ & 30 & [129-132] \\
\hline Corrosion Resistance & High & Good & Excellent & Good & Average & Poor & Good & Good & [133-135] \\
\hline Biocompatibility & Excellent & Good & Excellent & Average & Excellent & Excellent & Excellent & Good & [134-136] \\
\hline
\end{tabular}




\section{Applications}

Metals have been widely used in different applications in recent last years. Not only can they be used in the automotive or aeronautical sectors, but also in the medical field. Within medicine, they can be employed for several purposes: scaffolds, implants, surgical guides, fixation guides, etc. The main applications of 3D printed metals in the manufacture of implants are presented in the following subsections.

Nowadays, many implants such as the hip or knee prostheses are manufactured in metallic materials. This is due to their high mechanical and fatigue strength and the easiness to manufacture them with conventional machining processes. Some authors have attempted to print prostheses by means of AM technologies. Unlike other manufacturing processes such as casting, AM technologies allow customized prostheses to be manufactured in serial batches without incurring excessive costs.

Several kinds of implants are available: cranial, maxillofacial, spinal, hip, knee, or skeletal reconstruction implants [12] among others. The ISO 5832 standard summarizes the characteristics, as well as the test methods, of the material to be used in metallic implants. For example, ISO 5832-1 [137] corresponds to wrought stainless steel, ISO 5832-3 to wrought titanium 6-aluminium 4-vanadium alloy [138], and ISO 5832-4 [139] corresponds to cobalt-chromium-molybdenum alloys.

The following subsections present the recent advances in metallic implants manufactured by AM methods, for cranial implants, maxillofacial implants, spinal implants, upper \& lower limb implants, and dental implants.

\subsection{Cranial Implants}

Moiduddin et al. reported a Ti-6Al-4V mesh cranial insert, manufactured with the EBM technique, with a porosity level of $49.81 \%$ and pore size diameter of $700 \mu \mathrm{m}$ [140] (Figure 5). Mazzoli et al. obtained customized titanium cranial implants with the EBM technology [141].

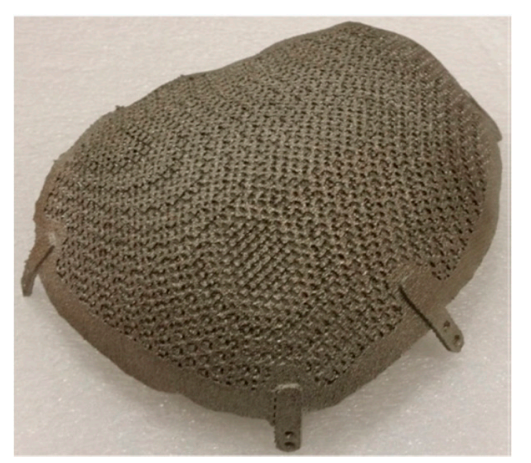

Figure 5. Cranial implant 3Dprinted in titanium with the EBM technique [140]. Reprinted from Electronic Journal of Biotechnology, 29, K. Moiduddin, S. Darwish, A. Al-Ahmari, Sh. ElWatidy, A. Mohammad, W. Ameen, Structural and mechanical characterization of custom design cranial implant created using additive manufacturing, 22-31, Copyright (2017), with permission from Elsevier.

Jardini et al. [12] manufactured cranial implants with direct metal laser sintering (DMLS, same technology as SLM)). The Ti-6Al-4V alloy was used (Figure 2a).

\subsection{Maxillofacial Implants}

Suska et al. [142] used EBM of Ti-6Al-4V alloy to manufacture a jaw prosthesis, which was individually designed and implanted, with a good aesthetic outcome (Figure 6). They added diamond-like porous structures to the upper and lower parts of the implant to favor the fixation of the prosthesis by means of osseointegration. The strut size employed was $0.3 \mathrm{~mm}$ and the pore size was $0.8 \mathrm{~mm}$. Yan et al. [143] employed Ti-6Al-4V titanium alloy to manufacture a mandibular prosthesis with a 3D mesh by means of EBM. The mesh porosity was $81.38 \%$ and the strut size, $0.7 \mathrm{~mm}$. 
Moiduddin et al. obtained a titanium zygomatic implant with the EBM technique, using Ti-6Al-4V ELI (extra low interstitial) powder [144]. The same author [145] compared different kinds of Ti-6Al-4V ELI mandibular implants for goats: EBM plate with mesh, EBM titanium plate without mesh and a commercial reconstruction plate. They found that the reconstructed plates with mesh showed a better fit than the other ones. They obtained a very good fit with titanium alloy mandibular implants [146].

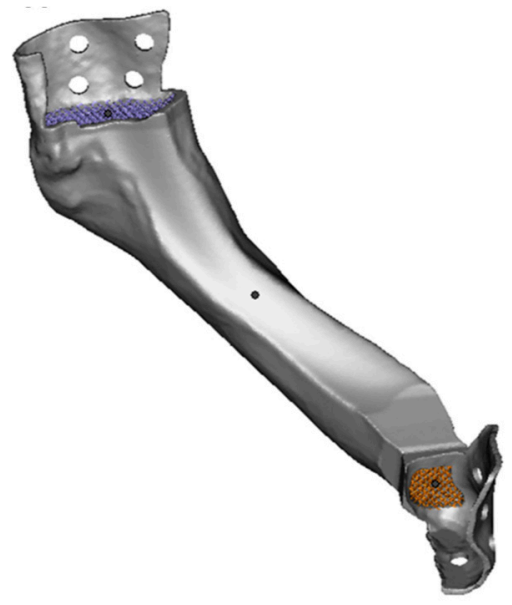

Figure 6. Printed jaw prosthesis with the DMLS technique [142]. Reprinted from Journal of Oral and Maxillofacial Surgery, 74(8), F.Suska, G.Kjeller, P.Tarnow, E.Hryha, L. Nyborg, A.Snis, A.Palmquist, Electron Beam Melting Manufacturing Technology for Individually Manufactured Jaw Prosthesis: A Case Report, 1706.e1-1706.e15, Copyright (2016), with permission from Elsevier.

Ciocca et al. [147] built DMLS titanium alloy meshes for the regeneration of atrophic maxillary arches. They used a $0.6 \mathrm{~mm}$ thickness mesh. Jardini et al. [148] manufactured Ti-6Al-4V parts for maxillofacial implants, using the DMLS technology. The same technology and material was used to obtain customized parts for upper maxillary implants [149].

\subsection{Spinal Implants}

Yang et al. [150] used the EBM technique to obtain Ti-6Al-4V vertebral bodies of sheep. Xu et al. [151] manufactured vertebral implants with the EBM technique and Ti-6Al-4V material, and Li et al. [152] tested porous artificial vertebral bodies in vivo, manufactured with the same material and technique. Choy et al. [14] printed titanium porous vertebral prostheses and performed in vivo spinal surgery. Siu et al. [153] applied EBM to obtain Ti-6Al-4V interbody cages for the lumbar area, in a case study with a deformity caused by osteoporotic fractures.

Hollander et al. [154] used direct laser forming (DLF) to obtain Ti-6Al-4V alloy vertebral bodies (Figure 7). They manufactured meshes with nominal pore sizes of 500, 700, and $1000 \mu \mathrm{m}$, which were reduced by $300 \mu \mathrm{m}$ after the process. The prostheses' surfaces allowed the growth of human osteoblasts.

McGilvray et al. [99] compared the performance of polyetheretherketone (PEEK), titanium-coated PEEK and 3D printed porous titanium alloy with regard to the manufacture of interbody fusions of the lumbar area of sheep. They reported higher cell ingrowth in titanium implants than in PEEK or titanium-coated PEEK cages. 


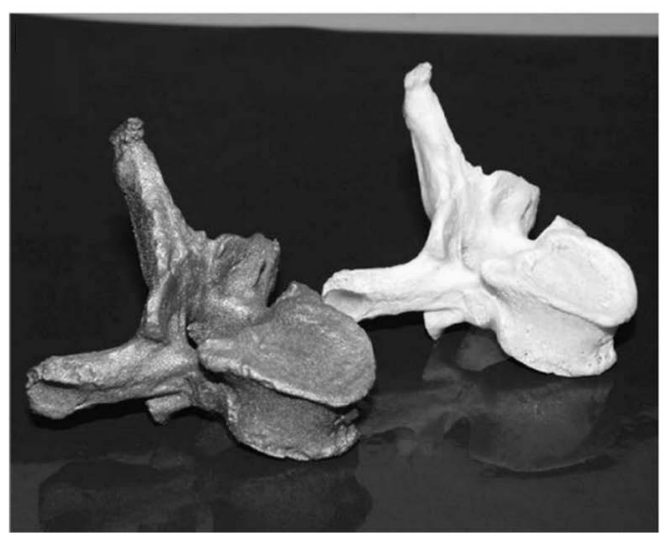

Figure 7. Printed spinal titanium alloy prosthesis obtained with the SLM technique [154]. Reprinted from Biomaterials, 27, Dirk A. Hollander, M.von Walter, T.Wirtz, R.Sellei, B.Schmidt-Rohlfing, O.Paar, H.-J.Erli, Structural, mechanical and in vitro characterization of individually structured Ti-6Al-4V produced by direct laser forming, 955-963, Copyright (2006), with permission from Elsevier.

\subsection{Upper Limb Prostheses}

Zou et al. [155] obtained customized macro-porous shoulder Ti-6Al-4V prostheses with the EBM technique, implanted them and observed good short-term follow-up effects. In 2017, the same process was used for the first time to manufacture a mold to cast a titanium first metacarpal hand implant [156].

\subsection{Chest Implants}

In 2013, Turna et al. reported the first 3D-printed chest implant [157]. It consisted of a plate for sternum and ribs. Aranda et al. obtained a more advanced implant in 2015 [158]. Aragón and Méndez manufactured a more flexible implant [159]. In 2017, a titanium chest implant was manufactured with the EBM technique, and further fixed [160], showing the versatility of the 3D-printing processes to obtain complex shapes. A clavicle was reconstructed in pure Ti by means of EBM [161].

\subsection{Pelvic Implants}

A pelvic specific implant was manufactured in Ti-6Al-4-V with EBM and subsequently implanted [162].

Another pelvic patient-specific implant was manufactured with a laser powder bed fusion technology [163].

\subsection{Lower Limb Prostheses}

Cronskar et al. [42] produced Ti6Al4V hip stems by means of EBM. They reported a reduction of the fatigue limit using the rough surfaces obtained by 3D printing when compared to conventional machining. Murr [164] reported a Ti-6Al-4 V porous acetabular cup, manufactured with the EBM technique (Figure 8).

Weißmann et al. [165] manufactured titanium alloy porous acetabular cups with the SLM technique. They tested three types of cells: twisted, combined and combined open, and found that their mechanical strength depends on the geometry of the unit cell employed, its dimensions and the volume and porosity responsible for the press fit of the prosthesis. A custom-made component of a hip implant endoprosthesis was obtained in titanium alloy with the same technique. The implant matched the anatomical features of the patient, with porous structures to favor osseointegration, and with good mechanical properties [166].

Xiu et al. [167] made Ti-6Al-4V femur condyle porous implants with the EBM technique, with $\mathrm{TiO}_{2} / \mathrm{CaP}$ coatings. A pore size of $640 \mu \mathrm{m}$, strut diameter of $400 \mu \mathrm{m}$, and porosity of $73 \%$ were used. 


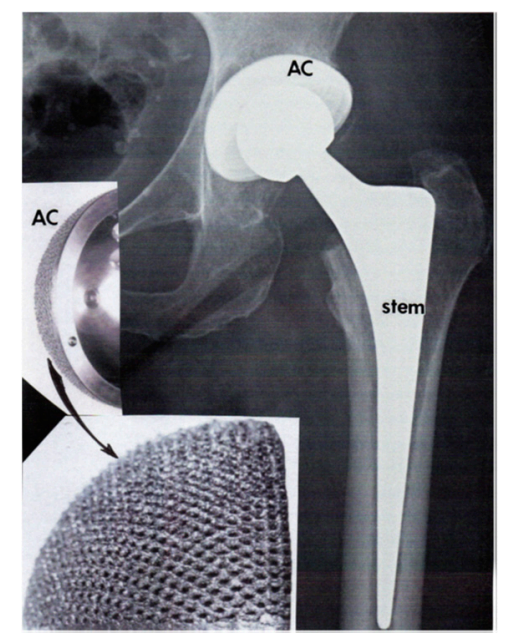

Figure 8. Printed acetabular cup with the EBM technique [164]. Reprinted from Journal of Material Science \& Technology, 35(2), L.R Murr, Strategies for creating living, additively manufactured, open-cellular metal and alloy implants by promoting osseointegration, osteoinduction and vascularization: An overview, 231-241, Copyright (2019), with permission from Elsevier.

Croitoru et al. [168] printed porous Ti6Al4V femoral stems for a hip replacement using powder bed fusion technology (laser sintering). They found that large fenestrations confer an elastic behavior to the structure while also contributing to enhance osseointegation. Arabnejad et al. [16] manufactured a titanium alloy stem taper-wedge implant with selective laser melting (SLM) (Figure 2e). They reported high mechanical strength with reduced stress-shielding, while the implant respected bone in-growth. Femoral implants have also been obtained with SLM in CoCrMo alloys [169].

Ruppert et al. [170] compared the performance of femoral implants manufactured by both the EBM and the SLM methods. Osseointegration was evaluated by means of mechanical testing. Coarse EBM implants showed higher removal torque than fine DMLS implants.

Murr et al. [171] made EBM porous structures for knee replacement, with Co-29Cr-6Mo alloy as the femoral and Ti-6Al-4V as the tibial component of the knee prostheses. Liu et al. used the same technique with titanium alloy as material to manufacture porous knee prostheses [172].

\subsection{Dental Implants}

Dental restorations have been obtained with the SLM technology [173]. Tolochko et al. used the combination of SLS and SLM to obtain titanium dental implants [174]. CoCrMo alloys have also been employed for the same purpose, with SLM processes [175-177].

Ortorp et al. [178] compared four different manufacturing techniques to obtain CrCo dental prostheses: lost wax casting, lost wax with milled wax, milling, and direct laser metal sintering (DLMS). The best fit was reported for the DLMS technique.

\subsection{Implants in General}

The binder jetting technology was used to manufacture stainless steel bone scaffolds [179]. Four different lattices were studied, and it was observed that mechanical strength depends on the type of lattice. Sintering time and temperature also influence mechanical strength. Porous titanium parts have been characterized in order to use them as implants [180].

The DED technique has been employed, for example, to obtain functionally graded structure in Ti-Mo alloys [181].

As an example of the extrusion processes (FFF or FDM), polylactic acid (PLA) and polyethene terephthalate (PET) polymeric filaments mixed with stainless steel $316 \mathrm{~L}$ and copper alloy Cu-10Sn allowed for the printing of multi-material parts [182]. 


\subsection{Comparison of the AM Techniques and Materials Used for Metallic Implants}

Table 19 shows a comparison among the different AM technologies used to manufacture implants. The figures in the table denote the number of papers corresponding to each technique and material that are presented in Section 4 of the present paper.

Table 19. Comparison of the metals and alloys used for implants.

\begin{tabular}{ccccc}
\hline Technique & Ti Alloys/Ti & CoCr alloys & Stainless Steel & References \\
\hline Binder Jetting (BJ) & & & 1 & {$[179]$} \\
Selective Laser & 11 & 5 & & {$[12,16,147,148,154,163,165,166,168-170,174-178]$} \\
Melting (SLM) & & 1 & & {$[11,42,140-145,150-153,160-162,170-172]$} \\
Electron Beam & 17 & & & {$[181]$} \\
Melting (EBM) & & & & {$[182]$} \\
Direct Energy & 1 & & 1 & \\
Deposition (DED) & & & & \\
Fused Filament & & & & \\
Fabrication (FFF) & & & & \\
\hline
\end{tabular}

As can be observed in Table 19, the largest number of references in the present paper corresponds to titanium alloys, firstly with the EBM technique and secondly with the SLM technique. They are followed by far by other technologies like BJ, EBM and FFF. Both EBM and SLM are powder bed fusion technologies. According to Table 6, both technologies have in common high dimensional accuracy and high corrosion resistance of the parts, because of the use of inert atmospheres. SLM provides higher resolution and part complexity than EBM. However, printing speed of EBM is higher than that of SLM, and it is cheaper. In EBM, only conductive alloys are used. On the contrary, SLM can be used for different alloys such as Inconel, stainless steel, etc.

In the following paragraphs, the impact of EBM and SLM techniques on biocompatibility, porosity, mechanical performance, and biodegradability of the implants is addressed.

Nowadays, the concept of biocompatibility means not only that a metal should be non-toxic but also that it should have a positive effect when interacting with living cells [183]. The three most employed materials for implants, Ti alloys, $\mathrm{CoCr}$ alloys and stainless-steel show high biocompatibility with the human body. However, high temperature AM processes such as EBM and SLM modify the physical, chemical and mechanical properties of the alloys, which are related to biocompatibility. In this line, Wang et al. found good haemocompatibility, no dermal irritation and no skin allergic reaction of Ti-6Al-4V alloy with both EBM and SLM processes [184]. In another comparative study between EBM and SLM processes, it was observed that SLM manufactured commercially pure titanium (CP-Ti) scaffolds presented higher cell viability and cell adhesion than EBM manufactured Ti-6Al-4V (Ti64) scaffolds [185]. The surface finish of the printed parts is an important factor influencing biocompatibility, since it affects the cell attachment, proliferation and differentiation [38]. Low roughness values below $2.0 \mu \mathrm{m}$ were reported to improve bone regeneration in titanium implants [186]. However, SLM and EBM lead to higher roughness values of 5-20 $\mu \mathrm{m}$ and 20-50 $\mu \mathrm{m}$ respectively [187]. In order to reduce roughness and improve cell adhesion along with cell proliferation, for example, the laser polishing operation can be applied [177].

The porosity of implants is directly related to cell growth. For example, the porosity of the cancellous bone ranges from 50\% to $90 \%$ [77]. As for pore size, a certain variability is required, with small pores to improve cell attachment and large pores that favor nutrient transport [78]. For example, pore size values between 200 and $1000 \mu \mathrm{m}$ are desirable in trabecular structures [117,188]. In addition, pores should be interconnected, in order to favor permeability and nutrient transport [80]. Regarding porosity, EBM combined with hot isostatic pressing achieved density values that were higher than $99 \%$, while SLM did not exceed 97\% [189]. Heinl al. manufactured different Ti-6Al-4V porous structures with interconnected porosity for bone implants, using selective electron beam melting (SEBM) [190]. Xue et al. used laser engineered direct shaping (LENS, a DED AM technology) to manufacture titanium 
porous implants for bone replacement [191]. Similar structures to those of the cancellous bone have been printed in titanium with the SLM technique [192].

High mechanical strength is important to protect patients with implants from fractures [193]. Titanium and some of its alloys have good mechanical properties, including high strength, a quite suitable elastic modulus, high fracture toughness and high fatigue strength [194]. However, additive manufacturing processes affect the properties of the material. For example, the compression strength of titanium aluminides obtained with the EBM technique, with preheating of the material and vacuum surrounding, were similar to those of the wrought material [189]. The higher the preheating, the lower the residual stresses are in EBM. Excellent wear properties were also reported in EBM processes in the transverse direction [189]. SLM manufactured titanium alloys also presented good mechanical properties [104]. On the other hand, metal implants should mimic the elastic modulus of bones. However, usually titanium alloys have higher elastic modulus values (around 112 GPa) [195] than those of the cortical bone, ranging from 7.7 to $21.8 \mathrm{GPa}$ [196,197]. For this reason, porous structures can be built that reduce the elastic modulus of solid materials [198].

Biodegradability is another important property of the metallic implants. Alloys can be divided into two groups with regard to their biodegradability: materials with high mechanical properties but lower biodegradability such as stainless steel, titanium and CrCo alloys, and metals or alloys with higher biodegradability but lower mechanical strength such as zinc, magnesium and iron [117]. For example, Ti and stainless steel structures do not degrade significantly with time, remaining in the body as a foreign object [195]. This can lead to several diseases such as infections, physical irritation, inflammatory reaction, etc. [199].

\section{Conclusions}

In recent years, additive manufacturing has been successfully incorporated into the manufacture of metallic implants, thanks to the possibility to obtain customized parts with porous structures that favor cell growth and osseointegration. The main conclusions are summarized next:

(1) The most-used metals in AM manufactured implants are titanium, titanium alloys, $\mathrm{CoCr}$ alloys, and stainless steel, mainly because of their high mechanical properties and biocompatibility. In addition, as a general trend, they maintain their properties when the parts are additively manufactured

(2) The most popular techniques to obtain AM metallic implants are EBM and SLM. Both technologies belong to the powder bed fusion group, and both of them provide high dimensional accuracy and high corrosion resistance. EBM uses higher printing speed than SLM, and it is cheaper. On the contrary, SLM allows higher resolution, better surface finish and higher part complexity than EBM.

(3) Several examples are available in the literature of cranial, mandibular, spinal, and upper \& lower limb titanium alloy implants, among others, manufactured with EBM and/or SLM techniques.

(4) The use of BJ, DED, or FFF to manufacture metallic implants is still at an early stage, in which metallic structures have been obtained and characterized, but with few in vivo tests. Further research is required in order to use these technologies in implants.

The application of AM technologies to the manufacture of metallic implants is still under development. Both the improvement of the printing technologies and the research investigating new alloys will help to consolidate the use of AM technologies for this purpose.

Author Contributions: Conceptualization, I.B.-C. and A.T.-O.; methodology, I.B.-C. and A.T.-O.; formal analysis, F.F.-A.; investigation, I.B.-C.; resources, I.B.-C.; writing-original draft preparation, A.T.-O. and I.B.-C.; writing-review and editing, I.B.-C., A.T.-O and F.F.-A.; visualization, A.T.-O.; supervision, I.B.-C.; project administration, A.T.-O. and I.B.-C.; funding acquisition, I.B.-C. All authors have read and agreed to the published version of the manuscript.

Funding: This project was co-financed by the European Union Regional Development Fund within the framework of the ERDF Operational Program of Catalonia 2014-2020 with a grant of 50\% of total cost eligible, project BASE3D, grant number 001-P-001646.

Conflicts of Interest: The authors declare no conflict of interest. 


\section{References}

1. Wohlers, T. Wohlers Report 2014. 3D Printing and Additive Manufcturing State of the Industry; Wohlers Associates: Fort Collins, CO, USA, 2014; p. 226.

2. Polonio-Alcalá, E.; Rabionet, M.; Guerra, A.J.; Yeste, M.; Ciurana, J.; Puig, T. Screening of additive manufactured scaffolds designs for triple negative breast cancer 3D cell culture and stem-like expansion. Int. J. Mol. Sci. 2018, 19, 3148. [CrossRef] [PubMed]

3. Tejo-Otero, A.; Buj-Corral, I.; Fenollosa-Artés, F. 3D Printing in Medicine for Preoperative Surgical Planning: A Review. Ann. Biomed. Eng. 2020, 48, 536-555. [CrossRef] [PubMed]

4. Muguruza Blanco, A.; Krauel, L.; Fenollosa Artés, F. Development of a patients-specific 3D-printed preoperative planning and training tool, with functionalized internal surfaces, for complex oncologic cases. Rapid Prototyp. J. 2019, 25, 363-377. [CrossRef]

5. Fenollosa, F.; Gomà, J.R.; Buj-Corral, I.; Otero, A.T.; Minguella-Canela, J.; Uceda, R.; Valls, A.; Ayats, M. Foreseeing new multi-material FFF-Additive Manufacturing concepts meeting mimicking requirements with living tissues. Procedia Manuf. 2019, 41, 1063-1070. [CrossRef]

6. Krauel, L.; Fenollosa, F.; Riaza, L.; Pérez, M.; Tarrado, X.; Morales, A.; Gomà, J.; Mora, J. Use of 3D Prototypes for Complex Surgical Oncologic Cases. World J. Surg. 2016, 40, 889-894. [CrossRef]

7. Tejo-Otero, A.; Lustig-Gainza, P.; Fenollosa-Artés, F.; Valls, A.; Krauel, L.; Buj-Corral, I. 3D printed soft surgical planning prototype for a biliary tract rhabdomyosarcoma. J. Mech. Behav. Biomed. Mater. 2020, 109, 1-11. [CrossRef]

8. Buj-Corral, I.; Bagheri, A.; Petit-Rojo, O. 3D Printing of Porous Scaffolds with Controlled Porosity and Pore Size Values. Materials 2018, 11, 1532. [CrossRef]

9. Buj-Corral, I.; Petit-Rojo, O.; Bagheri, A.; Minguella-Canela, J. Modelling of porosity of 3D printed ceramic prostheses with grid structure. Procedia Manuf. 2017, 13, 770-777. [CrossRef]

10. Bibb, R.; Eggbeer, D.; Evans, P.; Bocca, A.; Sugar, A. Rapid manufacture of custom-fitting surgical guides. Rapid Prototyp. J. 2009, 15, 346-354. [CrossRef]

11. Shah, K.; Lee, D.J. Fabricating a screw-retained, complete arch, fixed implant prosthesis using selective metal laser sintering: A clinical report. J. Prosthet. Dent. 2020, 123, 373-378. [CrossRef]

12. Murr, L.E. Open-cellular metal implant design and fabrication for biomechanical compatibility with bone using electron beam melting. J. Mech. Behav. Biomed. Mater. 2017, 76, 164-177. [CrossRef] [PubMed]

13. Jardini, A.L.; Larosa, M.A.; Filho, R.M.; Zavaglia, C.A.D.C.; Bernardes, L.F.; Lambert, C.S.; Calderoni, D.R.; Kharmandayan, P. Cranial reconstruction: 3D biomodel and custom-built implant created using additive manufacturing. J. Cranio-Maxillofacial Surg. 2014, 42, 1877-1884. [CrossRef] [PubMed]

14. Chen, J.; Zhang, Z.; Chen, X.; Zhang, C.; Zhang, G.; Xu, Z. Design and manufacture of customized dental implants by using reverse engineering and selective laser melting technology. J. Prosthet. Dent. 2014, 112, 1088-1095.E1. [CrossRef]

15. Choy, W.J.; Mobbs, R.J.; Wilcox, B.; Phan, S.; Phan, K.; Sutterlin, C.E. Reconstruction of Thoracic Spine Using a Personalized 3D-Printed Vertebral Body in Adolescent with T9 Primary Bone Tumor. World Neurosurg. 2017, 105, 1032.e13-1032.e17. [CrossRef] [PubMed]

16. Chen, X.; Possel, J.K.; Wacongne, C.; van Ham, A.F.; Klink, P.C.; Roelfsema, P.R. 3D printing and modelling of customized implants and surgical guides for non-human primates. J. Neurosci. Methods 2017, 286, 38-55. [CrossRef] [PubMed]

17. Arabnejad, S.; Johnston, B.; Tanzer, M.; Pasini, D. Fully porous 3D printed titanium femoral stem to reduce stress-shielding following total hip arthroplasty. J. Orthop. Res. 2017, 35, 1774-1783. [CrossRef]

18. ASTM F2792 - 12a. Standard Terminology for Additive Manufacturing Technologies (Withdrawn 2015); ASTM International: West Conshohocken, PA, USA, 2012.

19. Tran, T.Q.; Chinnappan, A.; Lee, J.K.Y.; Loc, N.H.; Tran, L.T.; Wang, G.; Kumar, V.V.; Jayathilaka, W.A.D.M.; Ji, D.; Doddamani, M.; et al. 3D printing of highly pure copper. Metals 2019, 9, 756. [CrossRef]

20. Elliott, A.; Alsalihi, S.; Merriman, A.L.; Basti, M.M. Infiltration of nanoparticles into porous binder jet printed parts. Am. J. Eng. Appl. Sci. 2016, 9, 128-133. [CrossRef] 
21. Varotsis, A.B. Introduction to Binder Jetting 3D Printing. Available online: https://www.3dhubs.com/ knowledge-base/introduction-binder-jetting-3d-printing/\%0Ahttps://www.3dhubs.com/knowledge-base/ introduction-binder-jetting-3d-printing/\%0Ahttp://files/92/introduction-binder-jetting-3d-printing.html (accessed on 28 April 2020).

22. Kumar, A.; Bai, Y.; Eklund, A.; Williams, C.B. Effects of Hot Isostatic Pressing on Copper Parts Fabricated via Binder Jetting. Procedia Manuf. 2017, 10, 935-944. [CrossRef]

23. Production System. Available online: https://www.desktopmetal.com/products/production/ (accessed on 28 April 2020).

24. Popovich, A.; Sufiiarov, V. Metal Powder Additive Manufacturing. In New Trends in 3D Printing; Intech Open: London, UK, 2016.

25. Nachum, S.; Vogt, J.; Raether, F. Additive manufacturing of ceramics: Stereolithography versus binder jetting. CFI Ceram. Forum Int. 2016, 93, E27-E33.

26. Ziaee, M.; Crane, N.B. Binder jetting: A review of process, materials, and methods. Addit. Manuf. 2019, 28, 781-801. [CrossRef]

27. Snelling, D.A.; Williams, C.B.; Druschitz, A.P. Mechanical and material properties of castings produced via 3D printed molds. Addit. Manuf. 2019, 27, 199-207. [CrossRef]

28. Enrique, P.D.; Mahmoodkhani, Y.; Marzbanrad, E.; Toyserkani, E.; Zhou, N.Y. In situ formation of metal matrix composites using binder jet additive manufacturing (3D printing). Mater. Lett. 2018, 232, 179-182. [CrossRef]

29. Cordero, Z.C.; Siddel, D.H.; Peter, W.H.; Elliott, A.M. Strengthening of ferrous binder jet 3D printed components through bronze infiltration. Addit. Manuf. 2017, 15, 87-92. [CrossRef]

30. Jurisch, M.; Studnitzky, T.; Andersen, O.; Kieback, B. 3D screen printing for the fabrication of small intricate Ti-6Al-4V parts. Powder Metall. 2015, 58, 339-343. [CrossRef]

31. Sa'ude, N.; Ibrahim, M.; Ismail, N.A.; Ibrahim, R. Freeform fabrication of titanium based powder by inkjet 3D printer. In Proceedings of the 6th International Conference on Leading Edge Manufacturing in 21st Century: LEM 21 2011.6, Omita Sonic City, Saitama, Japan, 8-10 November 2011.

32. Bai, Y.; Wagner, G.; Williams, C.B. Effect of particle size distribution on powder packing and sintering in binder jetting additive manufacturing of metals. J. Manuf. Sci. Eng. Trans. ASME 2017, 139, 081019. [CrossRef]

33. SLM Solutions. Available online: https://www.slm-solutions.com/en/products/machines/ selectivelasermeltingmachines/ (accessed on 28 April 2020).

34. Levy, G.N.; Schindel, R.; Kruth, J.P. Rapid manufacturing and rapid tooling with layer manufacturing (LM) technologies, state of the art and future perspectives. CIRP Ann. Manuf. Technol. 2003, 52, 589-609. [CrossRef]

35. Leuders, S.; Thöne, M.; Riemer, A.; Niendorf, T.; Tröster, T.; Richard, H.A.; Maier, H.J. On the mechanical behaviour of titanium alloy TiAl6V4 manufactured by selective laser melting: Fatigue resistance and crack growth performance. Int. J. Fatigue 2013, 48, 300-307. [CrossRef]

36. Moore, J.D.; Klemm, D.; Lindackers, D.; Grasemann, S.; Träger, R.; Eckert, J.; Löber, L.; Scudino, S.; Katter, M.; Barcza, A.; et al. Selective laser melting of $\mathrm{La}(\mathrm{Fe}, \mathrm{Co}, \mathrm{Si}) 13$ geometries for magnetic refrigeration. J. Appl. Phys. 2013, 144, 043907. [CrossRef]

37. Koutsoukis, T.; Zinelis, S.; Eliades, G.; Al-Wazzan, K.; Al Rifaiy, M.; Al Jabbari, Y.S. Selective Laser Melting Technique of Co-Cr Dental Alloys: A Review of Structure and Properties and Comparative Analysis with Other Available Techniques. J. Prosthodont. 2015, 24, 303-312. [CrossRef]

38. Lesyk, D.A.; Martinez, S.; Mordyuk, B.N.; Dzhemelinskyi, V.V.; Lamikiz, A.; Prokopenko, G.I. Post-processing of the Inconel 718 alloy parts fabricated by selective laser melting: Effects of mechanical surface treatments on surface topography, porosity, hardness and residual stress. Surf. Coatings Technol. 2020, 381, 125136. [CrossRef]

39. Sidambe, A.T. Biocompatibility of advanced manufactured titanium implants-A review. Materials 2014, 7, 8168-8188. [CrossRef] [PubMed]

40. Gokuldoss, P.K.; Kolla, S.; Eckert, J. Additive manufacturing processes: Selective laser melting, electron beam melting and binder jetting-selection guidelines. Materials 2017, 10, 672. [CrossRef] [PubMed]

41. Körner, C. Additive manufacturing of metallic components by selective electron beam melting-A review. Int. Mater. Rev. 2016, 61, 361-377. [CrossRef] 
42. GE Additive Machines. Available online: https://www.ge.com/additive/additive-manufacturing/machines/ ebm-machines/arcam-ebm-q20plus (accessed on 28 April 2020).

43. Cronskär, M.; Bäckström, M.; Rännar, L.E. Production of customized hip stem prostheses-A comparison between conventional machining and electron beam melting (EBM). Rapid Prototyp. J. 2013, 19, 365-372. [CrossRef]

44. Mazak. Integrex i-400 AM. Available online: https://www.mazakusa.com/machines/integrex-i-400am/ (accessed on 28 April 2020).

45. DM 3D. Available online: http://www.pomgroup.com/index.php?option=com_content\&view=category\& id=103\&Itemid=919 (accessed on 28 April 2020).

46. Garmendia, I.; Pujana, J.; Lamikiz, A.; Madarieta, M.; Leunda, J. Structured light-based height control for laser metal deposition. J. Manuf. Process. 2019, 42, 20-27. [CrossRef]

47. Kies, F.; Wilms, M.B.; Pirch, N.; Pradeep, K.G.; Schleifenbaum, J.H.; Haase, C. Defect formation and prevention in directed energy deposition of high-manganese steels and the effect on mechanical properties. Mater. Sci. Eng. A 2020, 772, 138688. [CrossRef]

48. Halada, G.P.; Clayton, C.R. The intersection of design, manufacturing, and surface engineering. In Handbook of Environmental Degradation of Materials; Elsevier: Amsterdam, The Netherlands, 2005; ISBN 9780815517498.

49. Arrizubieta, J.I.; Lamikiz, A.; Klocke, F.; Martínez, S.; Arntz, K.; Ukar, E. Evaluation of the relevance of melt pool dynamics in Laser Material Deposition process modeling. Int. J. Heat Mass Transf. 2017, 115, 80-91. [CrossRef]

50. Markforged. Metal X System. Available online: https://markforged.com/metal-x/ (accessed on 28 April 2020).

51. Hwang, S.; Reyes, E.I.; Moon, K.; Rumpf, R.C.; Kim, N.S. Thermo-mechanical Characterization of Metal/Polymer Composite Filaments and Printing Parameter Study for Fused Deposition Modeling in the 3D Printing Process. J. Electron. Mater. 2015, 44, 771-777. [CrossRef]

52. Do, A.V.; Smith, R.; Acri, T.M.; Geary, S.M.; Salem, A.K. 3D printing technologies for 3D scaffold engineering. In Functional 3D Tissue Engineering Scaffolds: Materials, Technologies, and Applications; Woodhead Publishing: Cambridge, UK, 2018; ISBN 9780081009802.

53. Buj-Corral, I.; Domínguez-Fernández, A.; Durán-Llucià, R. Influence of print orientation on surface roughness in fused deposition modeling (FDM) processes. Materials 2019, 12, 3834. [CrossRef]

54. Liu, Z.; Lei, Q.; Xing, S. Mechanical characteristics of wood, ceramic, metal and carbon fiber-based PLA composites fabricated by FDM. J. Mater. Res. Technol. 2019, 8, 3741-3751. [CrossRef]

55. Liu, B.; Wang, Y.; Lin, Z.; Zhang, T. Creating metal parts by Fused Deposition Modeling and Sintering. Mater. Lett. 2020, 263, 127252. [CrossRef]

56. Lee, J.; Lee, H.; Cheon, K.H.; Park, C.; Jang, T.S.; Kim, H.E.; Jung, H. Do Fabrication of poly(lactic acid)/Ti composite scaffolds with enhanced mechanical properties and biocompatibility via fused filament fabrication (FFF)-based 3D printing. Addit. Manuf. 2019, 30, 100883.

57. Weiss, D. Advances in the Sand Casting of Aluminium Alloys. In Fundamentals of Aluminium Metallurgy; Woodhead Publishing: Sawston, UK, 2018.

58. Gaytan, S.M.; Murr, L.E.; Medina, F.; Martinez, E.; Lopez, M.I.; Wicker, R.B. Advanced metal powder based manufacturing of complex components by electron beam melting. Mater. Technol. 2009, 24, 180-190. [CrossRef]

59. Digital Alloys' Guide to metal Additive Manufacturing-Part 9. Directed Energy Deposition (DED). Available online: https://www.digitalalloys.com/blog/directed-energy-deposition/ (accessed on 15 January 2020).

60. Zanner, F.J. Vacuum Melting. In Encyclopedia of Materials: Science and Technology, 2nd ed.; Elsevier Ltd.: Sandia Park, NM, USA, 2004.

61. Alkaios Bournias Varotsis Introduction to SLA 3D Printing|3D Hubs. Available online: https://www.3dhubs.com/knowledge-base/introduction-sla-3d-printing/\%0Ahttps://www.3dhubs. com/knowledge-base/introduction-sla-3d-printing\#author\%0Ahttps://www.3dhubs.com/knowledge-base/ introduction-sla-3d-printing (accessed on 16 July 2018).

62. Frazier, W.E. Metal additive manufacturing: A review. J. Mater. Eng. Perform. 2014, 23, 1917-1928. [CrossRef]

63. Pastor-Artigues, M.-M.; Roure-Fernández, F.; Ayne.to-Gubert, X.; Bonada-Bo, J.; Pérez-Guindal, E.; Buj-Corral, I. Elastic Asymmetry of PLA Material in FDM-Printed Parts: Considerations Concerning Experimental Characterisation for Use in Numerical Simulations. Materials 2019, 13, 15. [CrossRef] 
64. Prashanth, K.G.; Scudino, S.; Eckert, J. Defining the tensile properties of Al-12Si parts produced by selective laser melting. Acta Mater. 2017, 126, 25-35. [CrossRef]

65. Liu, S.; Shin, Y.C. Additive manufacturing of Ti6Al4V alloy: A review. Mater. Des. 2019, 164, 107552. [CrossRef]

66. Wauthle, R.; Vrancken, B.; Beynaerts, B.; Jorissen, K.; Schrooten, J.; Kruth, J.P.; Van Humbeeck, J. Effects of build orientation and heat treatment on the microstructure and mechanical properties of selective laser melted Ti6Al4V lattice structures. Addit. Manuf. 2015, 5, 77-84. [CrossRef]

67. Tilton, M.; Lewis, G.S.; Bok Wee, H.; Armstrong, A.; Hast, M.W.; Manogharan, G. Additive manufacturing of fracture fixation implants: Design, material characterization, biomechanical modeling and experimentation. Addit. Manuf. 2020, 33, 101137. [CrossRef]

68. Caravaggi, P.; Liverani, E.; Leardini, A.; Fortunato, A.; Belvedere, C.; Baruffaldi, F.; Fini, M.; Parrilli, A.; Mattioli-Belmonte, M.; Tomesani, L.; et al. CoCr porous scaffolds manufactured via selective laser melting in orthopedics: Topographical, mechanical, and biological characterization. J. Biomed. Mater. Res. Part B Appl. Biomater. 2019, 107, 2343-2353. [CrossRef] [PubMed]

69. Tan, Z.E.; Pang, J.H.L.; Kaminski, J.; Pepin, H. Characterisation of porosity, density, and microstructure of directed energy deposited stainless steel AISI 316L. Addit. Manuf. 2019, 25, 286-296. [CrossRef]

70. Bettinger, C.J.; Borenstein, J.T.; Langer, R. Micro- and nanofabricated scaffolds. In Principles of Tissue Engineering, 3rd ed.; Elsevier Academic Press: Burlington, MA, USA; San Diego, CA, USA; London, UK, 2007; ISBN 9780123706157.

71. Gasman, L. Additive aerospace considered as a business. In Additive Manufacturing for the Aerospace Industry; Elsevier: Amsterdam, The Netherlands, 2019.

72. Emmelmann, C.; Scheinemann, P.; Munsch, M.; Seyda, V. Laser additive manufacturing of modified implant surfaces with osseointegrative characteristics. Phys. Procedia 2011, 12, 375-384. [CrossRef]

73. Zhao, B.; Wang, H.; Qiao, N.; Wang, C.; Hu, M. Corrosion resistance characteristics of a Ti-6Al-4V alloy scaffold that is fabricated by electron beam melting and selective laser melting for implantation in vivo. Mater. Sci. Eng. C 2017, 70, 832-841. [CrossRef] [PubMed]

74. Mirzababaei, S.; Pasebani, S. A Review on Binder Jet Additive Manufacturing of 316L Stainless Steel. J. Manuf. Mater. Process. 2019, 3, 82. [CrossRef]

75. Melia, M.A.; Nguyen, H.D.A.; Rodelas, J.M.; Schindelholz, E.J. Corrosion properties of 304L stainless steel made by directed energy deposition additive manufacturing. Corros. Sci. 2019, 152, 20-30. [CrossRef]

76. Digital Alloys' Guide to Metal Additive Manufacturing. Part 5: Economics of Metal Additive Manufacturing. 2019. Available online: https://www.digitalalloys.com/blog/economics-metal-additive-manufacturing/ (accessed on 28 April 2020).

77. Saini, M. Implant biomaterials: A comprehensive review. World J. Clin. Cases 2015, 3, 52-57. [CrossRef] [PubMed]

78. Webster, T.J. Nanotechnology for the Regeneration of Hard and Soft Tissues; World Scientific: Singapore, 2007; ISBN 9789812779656.

79. Daily Metal Prices. Available online: https://www.dailymetalprice.com/metalprices.php? $=\mathrm{fe} \& \mathrm{u}=\mathrm{kg} \& \mathrm{~d}=1$ (accessed on 7 May 2020).

80. Mantripragada, V.P.; Lecka-Czernik, B.; Ebraheim, N.A.; Jayasuriya, A.C. An overview of recent advances in designing orthopedic and craniofacial implants. J. Biomed. Mater. Res. Part A 2013, 101, 3349-3364. [CrossRef]

81. Ali, S.; Rani, A.M.A.; Mufti, R.A.; Hastuty, S.; Hussain, M.; Shehzad, N.; Baig, Z.; Aliyu, A.A.A. An efficient approach for nitrogen diffusion and surface nitriding of boron-titanium modified stainless steel alloy for biomedical applications. Metals 2019, 9, 755. [CrossRef]

82. Thomann, U.I.; Uggowitzer, P.J. Wear-corrosion behavior of biocompatible austenitic stainless steels. Wear 2000, 239, 48-58. [CrossRef]

83. Lodhi, M.J.K.; Deen, K.M.; Greenlee-Wacker, M.C.; Haider, W. Additively manufactured 316L stainless steel with improved corrosion resistance and biological response for biomedical applications. Addit. Manuf. 2019, 27, 8-19. [CrossRef]

84. Luo, J.; Jia, X.; Gu, R.; Zhou, P.; Huang, Y.; Sun, J.; Yan, M. 316L stainless steel manufactured by selective laser melting and its biocompatibility with or without hydroxyapatite coating. Metals 2018, 8, 548. [CrossRef] 
85. Sing, S.L.; An, J.; Yeong, W.Y.; Wiria, F.E. Laser and electron-beam powder-bed additive manufacturing of metallic implants: A review on processes, materials and designs. J. Orthop. Res. 2016, 34, 369-385. [CrossRef] [PubMed]

86. Fayazfar, H.; Salarian, M.; Rogalsky, A.; Sarker, D.; Russo, P.; Paserin, V.; Toyserkani, E. A critical review of powder-based additive manufacturing of ferrous alloys: Process parameters, microstructure and mechanical properties. Mater. Des. 2018, 144, 98-128. [CrossRef]

87. Correa, E.O.; Costa, S.C.; Santos, J.N. Weldability of iron-based powder metal materials using pulsed plasma arc welding process. J. Mater. Process. Technol. 2008, 198, 323-329. [CrossRef]

88. Shuai, C.; Yang, W.; Yang, Y.; Pan, H.; He, C.; Qi, F.; Xie, D.; Liang, H. Selective laser melted Fe-Mn bone scaffold: Microstructure, corrosion behavior and cell response. Mater. Res. Express 2019, 7, 015404. [CrossRef]

89. Dehestani, M.; Adolfsson, E.; Stanciu, L.A. Mechanical properties and corrosion behavior of powder metallurgy iron-hydroxyapatite composites for biodegradable implant applications. Mater. Des. 2016, 109, 556-569. [CrossRef]

90. Reilly, D.T.; Burstein, A.H. The elastic and ultimate properties of compact bone tissue. J. Biomech. 1975, 8, 393-405. [CrossRef]

91. Engineers Edge. Available online: https://www.engineersedge.com/materials/machinability-steel-aluminum. htm (accessed on 27 April 2020).

92. Bartolo, P.; Kruth, J.P.; Silva, J.; Levy, G.; Malshe, A.; Rajurkar, K.; Mitsuishi, M.; Ciurana, J.; Leu, M. Biomedical production of implants by additive electro-chemical and physical processes. CIRP Ann. Manuf. Technol. 2012, 61, 635-655. [CrossRef]

93. Bormann, T.; Schumacher, R.; Müller, B.; Mertmann, M.; De Wild, M. Tailoring selective laser melting process parameters for niti implants. J. Mater. Eng. Perform. 2012, 21, 2519-2524. [CrossRef]

94. Ou, S.F.; Peng, B.Y.; Chen, Y.C.; Tsai, M.H. Manufacturing and characterization of NiTi alloy with functional properties by selective laser melting. Metals 2018, 8, 342. [CrossRef]

95. Parida, A.K.; Maity, K. Comparison the machinability of Inconel 718, Inconel 625 and Monel 400 in hot turning operation. Eng. Sci. Technol. Int. J. 2018, 21, 264-370. [CrossRef]

96. Elias, C.N.; Lima, J.H.C.; Valiev, R.; Meyers, M.A. Biomedical applications of titanium and its alloys. JOM 2008, 60, 46-49. [CrossRef]

97. Taniguchi, N.; Fujibayashi, S.; Takemoto, M.; Sasaki, K.; Otsuki, B.; Nakamura, T.; Matsushita, T.; Kokubo, T.; Matsuda, S. Effect of pore size on bone ingrowth into porous titanium implants fabricated by additive manufacturing: An in vivo experiment. Mater. Sci. Eng. C 2016, 59, 690-701. [CrossRef] [PubMed]

98. Lütjering, G.; Williams, J.C. Titanium: Engineering Materials and Processes; Springer: Cham, Switzerland, 2007.

99. McGilvray, K.C.; Easley, J.; Seim, H.B.; Regan, D.; Berven, S.H.; Hsu, W.K.; Mroz, T.E.; Puttlitz, C.M. Bony ingrowth potential of 3D-printed porous titanium alloy: A direct comparison of interbody cage materials in an in vivo ovine lumbar fusion model. Spine J. 2018, 18, 1250-1260. [CrossRef] [PubMed]

100. Zhang, J.; Jung, Y.G. Additive Manufacturing: Materials, Processes, Quantifications and Applications; Elsevier: Amsterdam, The Netherlands, 2018; ISBN 9780128121559.

101. Bai, L.; Gong, C.; Chen, X.; Sun, Y.; Zhang, J.; Cai, L.; Zhu, S.; Xie, S.Q. Additive manufacturing of customized metallic orthopedic implants: Materials, structures, and surface modifications. Metals 2019, 9, 1004. [CrossRef]

102. Fousová, M.; Vojtěch, D.; Kubásek, J.; Jablonská, E.; Fojt, J. Promising characteristics of gradient porosity Ti-6Al-4V alloy prepared by SLM process. J. Mech. Behav. Biomed. Mater. 2017, 69, 368-376. [CrossRef]

103. Hao, Y.L.; Li, S.J.; Yang, R. Biomedical titanium alloys and their additive manufacturing. Rare Met. 2016, 35, 661-671. [CrossRef]

104. Chlebus, E.; Kuźnicka, B.; Kurzynowski, T.; Dybała, B. Microstructure and mechanical behaviour of Ti-6Al-7Nb alloy produced by selective laser melting. Mater. Charact. 2011, 62, 488-495. [CrossRef]

105. Szymczyk, P.; Ziółkowski, G.; Junka, A.; Chlebus, E. Application of Ti6Al7Nb alloy for the manufacture of biomechanical functional structures (BFS) for custom-made bone implants. Materials 2018, 11, 971. [CrossRef]

106. Attar, H.; Calin, M.; Zhang, L.C.; Scudino, S.; Eckert, J. Manufacture by selective laser melting and mechanical behavior of commercially pure titanium. Mater. Sci. Eng. A 2014, 593, 170-177. [CrossRef]

107. Cheng, X.; Liu, S.; Chen, C.; Chen, W.; Liu, M.; Li, R.; Zhang, X.; Zhou, K. Microstructure and mechanical properties of additive manufactured porous Ti-33Nb-4Sn scaffolds for orthopaedic applications. J. Mater. Sci. Mater. Med. 2019, 30, 91. [CrossRef] [PubMed] 
108. Elkaiam, L.; Hakimi, O.; Goldman, J.; Aghion, E. The effect of nd on mechanical properties and corrosion performance of biodegradable Mg-5\%Zn alloy. Metals 2018, 8, 438. [CrossRef]

109. Kraus, T.; Fischerauer, S.; Treichler, S.; Martinelli, E.; Eichler, J.; Myrissa, A.; Zötsch, S.; Uggowitzer, P.J.; Löffler, J.F.; Weinberg, A.M. The influence of biodegradable magnesium implants on the growth plate. Acta Biomater. 2018, 66, 109-117. [CrossRef] [PubMed]

110. Karunakaran, R.; Ortgies, S.; Tamayol, A.; Bobaru, F.; Sealy, M.P. Additive manufacturing of magnesium alloys. Bioact. Mater. 2020, 5, 44-54. [CrossRef] [PubMed]

111. Czerwinski, F. Controlling the ignition and flammability of magnesium for aerospace applications. Corros. Sci. 2014, 86, 1-16. [CrossRef]

112. Prasadh, S.; Ratheesh, V.; Manakari, V.; Parande, G.; Gupta, M.; Wong, R. The potential of Magnesium based Materials in Mandibular reconstruction. Metals 2019, 9, 302. [CrossRef]

113. Cheng, M.Q.; Wahafu, T.; Jiang, G.F.; Liu, W.; Qiao, Y.Q.; Peng, X.C.; Cheng, T.; Zhang, X.L.; He, G.; Liu, X.Y. A novel open-porous magnesium scaffold with controllable microstructures and properties for bone regeneration. Sci. Rep. 2016, 6, 24134. [CrossRef]

114. Thijs, L.; Montero Sistiaga, M.L.; Wauthle, R.; Xie, Q.; Kruth, J.P.; Van Humbeeck, J. Strong morphological and crystallographic texture and resulting yield strength anisotropy in selective laser melted tantalum. Acta Mater. 2013, 61, 4657-4668. [CrossRef]

115. Alvarez, K.; Nakajima, H. Metallic scaffolds for bone regeneration. Materials 2009, 2, 790-832. [CrossRef]

116. Sporer, S.; Della Valle, C.J.; Jacobs, J.J.; Paprosky, W.; Levine, B. Porous Tantalum in Reconstructive Surgery of the Knee. J. Knee Surg. 2007, 20, 185-194.

117. Su, Y.; Cockerill, I.; Wang, Y.; Qin, Y.X.; Chang, L.; Zheng, Y.; Zhu, D. Zinc-Based Biomaterials for Regeneration and Therapy. Trends Biotechnol. 2019, 27, 428-441. [CrossRef] [PubMed]

118. Yang, H.; Qu, X.; Lin, W.; Wang, C.; Zhu, D.; Dai, K.; Zheng, Y. In vitro and in vivo studies on zinc-hydroxyapatite composites as novel biodegradable metal matrix composite for orthopedic applications. Acta Biomater. 2018, 71, 200-214. [CrossRef] [PubMed]

119. Zhu, P.; Weng, Z.; Li, X.; Liu, X.; Wu, S.; Yeung, K.W.K.; Wang, X.; Cui, Z.; Yang, X.; Chu, P.K. Biomedical Applications of Functionalized ZnO Nanomaterials: From Biosensors to Bioimaging. Adv. Mater. Interfaces 2016, 3, 1500494. [CrossRef]

120. Jakus, A.E.; Secor, E.B.; Rutz, A.L.; Jordan, S.W.; Hersam, M.C.; Shah, R.N. Three-dimensional printing of high-content graphene scaffolds for electronic and biomedical applications. ACS Nano 2015, 9, 4636-4648. [CrossRef] [PubMed]

121. Guo, M.; Gu, D.; Xi, L.; Du, L.; Zhang, H.; Zhang, J. Formation of scanning tracks during Selective Laser Melting (SLM) of pure tungsten powder: Morphology, geometric features and forming mechanisms. Int. J. Refract. Met. Hard Mater. 2019, 79, 37-46. [CrossRef]

122. Weinmann, M.; Schnitter, C.; Stenzel, M.; Markhoff, J.; Schulze, C.; Bader, R. Development of bio-compatible refractory $\mathrm{Ti} / \mathrm{Nb}(/ \mathrm{Ta})$ alloys for application in patient-specific orthopaedic implants. Int. J. Refract. Met. Hard Mater. 2018, 75, 126-136. [CrossRef]

123. General Technical Knowledge. Melting Point of Carbon Steel \& Stainless Steel. Available online: https://shipbuildingknowledge.wordpress.com/2019/01/05/melting-point-of-carbon-steel-stainlesssteel/ (accessed on 7 May 2020).

124. Kim, H.R.; Jang, S.H.; Kim, Y.K.; Son, J.S.; Min, B.K.; Kim, K.H.; Kwon, T.Y. Microstructures and mechanical properties of Co-Cr dental alloys fabricated by three CAD/CAM-based processing techniques. Materials 2016, 9, 596. [CrossRef]

125. Sadeghpour, S.; Abbasi, S.M.; Morakabati, M.; Kisko, A.; Karjalainen, L.P.; Porter, D.A. A new multi-element beta titanium alloy with a high yield strength exhibiting transformation and twinning induced plasticity effects. Scr. Mater. 2018, 145, 104-108. [CrossRef]

126. Marinelli, G.; Martina, F.; Ganguly, S.; Williams, S. Microstructure, hardness and mechanical properties of two different unalloyed tantalum wires deposited via wire + arc additive manufacture. Int. J. Refract. Met. Hard Mater. 2019, 83, 104974. [CrossRef]

127. Fu, Y.; Zhang, Y.; Zhou, H.; Li, D.; Liu, H.; Qiao, H.; Wang, X. Timely online chatter detection in end milling process. Mech. Syst. Signal Process. 2016, 75, 668-688. [CrossRef]

128. Wang, C.; Yang, H.T.; Li, X.; Zheng, Y.F. In Vitro Evaluation of the Feasibility of Commercial Zn Alloys as Biodegradable Metals. J. Mater. Sci. Technol. 2016, 32, 909-918. [CrossRef] 
129. Krystýnová, M.; Doležal, P.; Fintová, S.; Březina, M.; Zapletal, J.; Wasserbauer, J. Preparation and characterization of zinc materials prepared by powder metallurgy. Metals 2017, 7, 396. [CrossRef]

130. Nor, M.S.M.; Salleh, Z.; Masdek, N.R.N.M.; Taib, Y.M.; Abu, M.Z. Electrodeposition of Co-Ni-Fe on stainless steel bolts. Int. J. Eng. Technol. 2018, 7, 221-225.

131. Tonelli, L.; Fortunato, A.; Ceschini, L. CoCr alloy processed by Selective Laser Melting (SLM): Effect of Laser Energy Density on microstructure, surface morphology, and hardness. J. Manuf. Process. 2020, 52, 106-119. [CrossRef]

132. Ghasali, E.; Alizadeh, M.; Shirvanimoghaddam, K.; Mirzajany, R.; Niazmand, M.; Faeghi-Nia, A.; Ebadzadeh, T. Porous and non-porous alumina reinforced magnesium matrix composite through microwave and spark plasma sintering processes. Mater. Chem. Phys. 2018, 212, 252-259. [CrossRef]

133. Ziętala, M.; Durejko, T.; Polański, M.; Kunce, I.; Płociński, T.; Zieliński, W.; Łazińska, M.; Stępniowski, W.; Czujko, T.; Kurzydłowski, K.J.; et al. The microstructure, mechanical properties and corrosion resistance of 316 L stainless steel fabricated using laser engineered net shaping. Mater. Sci. Eng. A 2016, 667, 1-10. [CrossRef]

134. Lin, W.; Qin, L.; Qi, H.; Zhang, D.; Zhang, G.; Gao, R.; Qiu, H.; Xia, Y.; Cao, P.; Wang, X.; et al. Long-term in vivo corrosion behavior, biocompatibility and bioresorption mechanism of a bioresorbable nitrided iron scaffold. Acta Biomater. 2017, 54, 454-468. [CrossRef]

135. Wang, N.; Li, H.; Wang, J.; Chen, S.; Ma, Y.; Zhang, Z. Study on the anticorrosion, biocompatibility, and osteoinductivity of tantalum decorated with tantalum oxide nanotube array films. ACS Appl. Mater. Interfaces 2012, 4, 4516-4523. [CrossRef]

136. Shang, Y.; Yuan, Y.; Li, D.; Li, Y.; Chen, J. Effects of scanning speed on in vitro biocompatibility of 316L stainless steel parts elaborated by selective laser melting. Int. J. Adv. Manuf. Technol. 2017, 92, 4379-4385. [CrossRef]

137. ISO 5832-1. Implants for Surgery-Metallic Materials_Part 1. Wrought Stainless Steel; ISO: Geneva, Switzerland, 2016.

138. ISO 5832-3. Implants for Surgery-Metallic Materials-Part 3. Wrought Titanium 6-Aluminium 4-Vanadium Alloy; ISO: Geneva, Switzerland, 2016.

139. Standardization, I.O. for ISO 5832-4: Implants for surgery-Metallic materials. In Part 4 Cobalt-chromium-molybdenum Cast. Alloy; ISO: Geneva, Switzerland, 2014.

140. Moiduddin, K.; Darwish, S.; Al-Ahmari, A.; ElWatidy, S.; Mohammad, A.; Ameen, W. Structural and mechanical characterization of custom design cranial implant created using additive manufacturing. Electron. J. Biotechnol. 2017, 29, 22-31. [CrossRef]

141. Mazzoli, A.; Germani, M.; Raffaeli, R. Direct fabrication through electron beam melting technology of custom cranial implants designed in a PHANToM-based haptic environment. Mater. Des. 2009, 30, 3186-3192. [CrossRef]

142. Suska, F.; Kjeller, G.; Tarnow, P.; Hryha, E.; Nyborg, L.; Snis, A.; Palmquist, A. Electron Beam Melting Manufacturing Technology for Individually Manufactured Jaw Prosthesis: A Case Report. J. Oral Maxillofac. Surg. 2016, 74, 1706.e1-1706.e15. [CrossRef] [PubMed]

143. Yan, R.; Luo, D.; Huang, H.; Li, R.; Yu, N.; Liu, C.; Hu, M.; Rong, Q. Electron beam melting in the fabrication of three-dimensional mesh titanium mandibular prosthesis scaffold. Sci. Rep. 2018, 8, 1-10. [CrossRef] [PubMed]

144. Moiduddin, K.; Mian, S.H.; Umer, U.; Ahmed, N.; Alkhalefah, H.; Ameen, W. Reconstruction of complex zygomatic bone defects using mirroring coupled with EBM fabrication of titanium implant. Metals 2019, 9, 1250. [CrossRef]

145. Moiduddin, K.; Mian, S.H.; Alkindi, M.; Ramalingam, S.; Alkhalefah, H.; Alghamdi, O. An in vivo evaluation of biocompatibility and implant accuracy of the electron beam melting and commercial reconstruction plates. Metals 2019, 9, 1065. [CrossRef]

146. Moiduddin, K.; Mian, S.H.; Alkhalefah, H.; Umer, U. Digital design, analysis and 3D printing of prosthesis scaffolds for mandibular reconstruction. Metals 2019, 9, 569. [CrossRef]

147. Ciocca, L.; Fantini, M.; De Crescenzio, F.; Corinaldesi, G.; Scotti, R. Direct metal laser sintering (DMLS) of a customized titanium mesh for prosthetically guided bone regeneration of atrophic maxillary arches. Med. Biol. Eng. Comput. 2011, 49, 1347-1352. [CrossRef] 
148. Jardini, A.L.; Larosa, M.A.; de Carvalho Zavaglia, C.A.; Bernardes, L.F.; Lambert, C.S.; Kharmandayan, P.; Calderoni, D.; Maciel Filho, R. Customised titanium implant fabricated in additive manufacturing for craniomaxillofacial surgery. Virtual Phys. Prototyp. 2014, 9, 115-125. [CrossRef]

149. Mazzoni, S.; Bianchi, A.; Schiariti, G.; Badiali, G.; Marchetti, C. Computer-aided design and computer-aided manufacturing cutting guides and customized titanium plates are useful in upper maxilla waferless repositioning. J. Oral Maxillofac. Surg. 2015, 73, 701-707. [CrossRef]

150. Yang, J.; Cai, H.; Lv, J.; Zhang, K.; Leng, H.; Sun, C.; Wang, Z.; Liu, Z. In vivo study of a self-stabilizing artificial vertebral body fabricated by electron beam melting. Spine 2014, 39, E486-E492. [CrossRef] [PubMed]

151. Xu, N.; Wei, F.; Liu, X.; Jiang, L.; Cai, H.; Li, Z.; Yu, M.; Wu, F.; Liu, Z. Reconstruction of the upper cervical spine using a personalized 3D-printed vertebral body in an adolescent with ewing sarcoma. Spine 2016, 41, E50-E54. [CrossRef] [PubMed]

152. Li, X.; Wang, Y.; Zhao, Y.; Liu, J.; Xiao, S.; Mao, K. Multilevel 3D Printing Implant for Reconstructing Cervical Spine with Metastatic Papillary Thyroid Carcinoma. Spine 2017, 42, E1326-E1330. [CrossRef] [PubMed]

153. Siu, T.L.; Rogers, J.M.; Lin, K.; Thompson, R.; Owbridge, M. Custom-Made Titanium 3-Dimensional Printed Interbody Cages for Treatment of Osteoporotic Fracture-Related Spinal Deformity. World Neurosurg. 2018, 111, 1-5. [CrossRef] [PubMed]

154. Hollander, D.A.; Von Walter, M.; Wirtz, T.; Sellei, R.; Schmidt-Rohlfing, B.; Paar, O.; Erli, H.J. Structural, mechanical and in vitro characterization of individually structured Ti-6Al-4V produced by direct laser forming. Biomaterials 2006, 27, 955-963. [CrossRef] [PubMed]

155. Zou, Y.; Yang, Y.; Han, Q.; Yang, K.; Zhang, K.; Wang, J.; Zou, Y. Novel exploration of customized 3D printed shoulder prosthesis in revision of total shoulder arthroplasty A case report. Medocine (United States) 2018, 97, e13282.

156. Punyaratabandhu, T.; Lohwongwatana, B.; Puncreobutr, C.; Kosiyatrakul, A.; Veerapan, P.; Luenam, S. A Patient-Matched Entire First Metacarpal Prosthesis in Treatment of Giant Cell Tumor of Bone. Case Rep. Orthop. 2017, 2017, 4101346. [CrossRef]

157. Turna, A.; Kavakli, K.; Sapmaz, E.; Arslan, H.; Caylak, H.; Gokce, H.S.; Demirkaya, A. Reconstruction with a patient-specific titanium implant after a wide anterior chest wall resection. Interact. Cardiovasc. Thorac. Surg. 2014, 18, 234-236. [CrossRef]

158. Aranda, J.L.; Jiménez, M.F.; Rodríguez, M.; Varela, G. Tridimensional titanium-printed custom-made prosthesis for sternocostal reconstruction. Eur. J. Cardio-Thorac. Surg. 2015, 48, e92-e94. [CrossRef]

159. Aragón, J.; Méndez, I.P. Dynamic 3D printed titanium copy prosthesis: A novel design for large chest wall resection and reconstruction. J. Thorac. Dis. 2016, 8, E385-E389. [CrossRef]

160. Moradiellos, J.; Amor, S.; Córdoba, M.; Rocco, G.; Vidal, M.; Varela, A. Functional Chest Wall Reconstruction With a Biomechanical Three-Dimensionally Printed Implant. Ann. Thorac. Surg. 2017, 103, e389-e391. [CrossRef] [PubMed]

161. Cronskär, M.; Rännar, L.E.; Bäckström, M.; Nilsson, K.G.; Samuelsson, B. Patient-Specific Clavicle Reconstruction Using Digital Design and Additive Manufacturing. J. Mech. Des. Trans. ASME 2015, 137, 111418, (4 pages). [CrossRef]

162. Wong, K.C.; Kumta, S.M.; Gee, N.V.L.; Demol, J. One-step reconstruction with a 3D-printed, biomechanically evaluated custom implant after complex pelvic tumor resection. Comput. Aided Surg. 2015, 20, 14-23. [CrossRef] [PubMed]

163. Liang, H.; Ji, T.; Zhang, Y.; Wang, Y.; Guo, W. Reconstruction with 3D-printed pelvic endoprostheses after resection of a pelvic tumour. Bone Jt. J. 2017, 99, 267-275. [CrossRef] [PubMed]

164. Murr, L.E. Strategies for creating living, additively manufactured, open-cellular metal and alloy implants by promoting osseointegration, osteoinduction and vascularization: An overview. J. Mater. Sci. Technol. 2019, 35, 231-241. [CrossRef]

165. Weißmann, V.; Boss, C.; Schulze, C.; Hansmann, H.; Bader, R. Experimental characterization of the primary stability of acetabular press-fit cups with open-porous load-bearing structures on the surface layer. Metals 2018, 8, 839. [CrossRef]

166. Popovich, A.; Sufiiarov, V.; Polozov, I.; Borisov, E.; Masaylo, D. Producing hip implants of titanium alloys by additive manufacturing. Int. J. Bioprinting 2016, 2, 78-84. [CrossRef] 
167. Xiu, P.; Jia, Z.; Lv, J.; Yin, C.; Cheng, Y.; Zhang, K.; Song, C.; Leng, H.; Zheng, Y.; Cai, H.; et al. Tailored Surface Treatment of 3D Printed Porous Ti6Al4V by Microarc Oxidation for Enhanced Osseointegration via Optimized Bone In-Growth Patterns and Interlocked Bone/Implant Interface. ACS Appl. Mater. Interfaces 2016, 8, 17964-17975. [CrossRef]

168. Croitoru, A.S.M.; Pacioga, B.A.; Comsa, C.S. Personalized hip implants manufacturing and testing. Appl. Surf. Sci. 2017, 417, 256-261. [CrossRef]

169. Song, C.; Yang, Y.; Wang, Y.; Wang, D.; Yu, J.K. Personalized femoral component design and its direct manufacturing by selective laser melting. Rapid Prototyp. J. 2016, 22, 330-337. [CrossRef]

170. Ruppert, D.S.; Harrysson, O.L.A.; Marcellin-Little, D.J.; Abumoussa, S.; Dahners, L.E.; Weinhold, P.S. Osseointegration of Coarse and Fine Textured Implants Manufactured by Electron Beam Melting and Direct Metal Laser Sintering. 3D Print. Addit. Manuf. 2017, 4, 91-97. [CrossRef] [PubMed]

171. Murr, L.E.; Amato, K.N.; Li, S.J.; Tian, Y.X.; Cheng, X.Y.; Gaytan, S.M.; Martinez, E.; Shindo, P.W.; Medina, F.; Wicker, R.B. Microstructure and mechanical properties of open-cellular biomaterials prototypes for total knee replacement implants fabricated by electron beam melting. J. Mech. Behav. Biomed. Mater. 2011, 4, 1396-1411. [CrossRef] [PubMed]

172. Liu, P.C.; Yang, Y.J.; Liu, R.; Shu, H.X.; Gong, J.P.; Yang, Y.; Sun, Q.; Wu, X.; Cai, M. A study on the mechanical characteristics of the EBM-printed Ti-6Al-4V LCP plates in vitro. J. Orthop. Surg. Res. 2014, 9, 106. [CrossRef] [PubMed]

173. Van Noort, R. The future of dental devices is digital. Dent. Mater. 2012, 28, 3-12. [CrossRef] [PubMed]

174. Tolochko, N.K.; Savich, V.V.; Laoui, T.; Froyen, L.; Onofrio, G.; Signorelli, E.; Titov, V.I. Dental root implants produced by the combined selective laser sintering/melting of titanium powders. Proc. Inst. Mech. Eng. Part L J. Mater. Des. Appl. 2002, 216, 267-270. [CrossRef]

175. Qian, B.; Saeidi, K.; Kvetková, L.; Lofaj, F.; Xiao, C.; Shen, Z. Defects-tolerant Co-Cr-Mo dental alloys prepared by selective laser melting. Dent. Mater. 2015, 31, 1435-1444. [CrossRef] [PubMed]

176. Averyanova, M.; Bertrand, P.; Verquin, B. Manufacture of $\mathrm{Co}-\mathrm{Cr}$ dental crowns and bridges by selective laser Melting technology. Virtual Phys. Prototyp. 2011, 6, 179-185. [CrossRef]

177. Vandenbroucke, B.; Kruth, J.P. Direct digital manufacturing of complex dental prostheses. In Bio-Materials and Prototyping Applications in Medicine; Springer: Boston, MA, USA, 2008; ISBN 9780387476827.

178. Örtorp, A.; Jönsson, D.; Mouhsen, A.; Vult Von Steyern, P. The fit of cobalt-chromium three-unit fixed dental prostheses fabricated with four different techniques: A comparative in vitro study. Dent. Mater. 2011, 27, 356-363. [CrossRef]

179. Vangapally, S.; Agarwal, K.; Sheldon, A.; Cai, S. Effect of Lattice Design and Process Parameters on Dimensional and Mechanical Properties of Binder Jet Additively Manufactured Stainless Steel 316 for Bone Scaffolds. Procedia Manuf. 2017, 10, 750-759. [CrossRef]

180. Basalah, A.; Shanjani, Y.; Esmaeili, S.; Toyserkani, E. Characterizations of additive manufactured porous titanium implants. J. Biomed. Mater. Res. Part B Appl. Biomater. 2012, 100, 1970-1979. [CrossRef]

181. Kang, N.; Lin, X.; El Mansori, M.; Wang, Q.Z.; Lu, J.L.; Coddet, C.; Huang, W.D. On the effect of the thermal cycle during the directed energy deposition application to the in-situ production of a Ti-Mo alloy functionally graded structure. Addit. Manuf. 2020, 31, 100911. [CrossRef]

182. Chueh, Y.H.; Wei, C.; Zhang, X.; Li, L. Integrated laser-based powder bed fusion and fused filament fabrication for three-dimensional printing of hybrid metal/polymer objects. Addit. Manuf. 2020, 31, 100928. [CrossRef]

183. Williams, D.F. There is no such thing as a biocompatible material. Biomaterials 2014, 35, 10009-10014. [CrossRef] [PubMed]

184. Wang, H.; Zhao, B.; Liu, C.; Wang, C.; Tan, X.; Hu, M. A comparison of biocompatibility of a titanium alloy fabricated by electron beam melting and selective laser melting. PLoS ONE 2016, 11, e0158513. [CrossRef]

185. Ataee, A.; Li, Y.; Wen, C. A comparative study on the nanoindentation behavior, wear resistance and in vitro biocompatibility of SLM manufactured CP-Ti and EBM manufactured Ti64 gyroid scaffolds. Acta Biomater. 2019, 97, 587-596. [CrossRef]

186. Wennerberg, A.; Albrektsson, T. Effects of titanium surface topography on bone integration: A systematic review. Clin. Oral Implants Res. 2009, 20, 172-184. [CrossRef]

187. Li, J.; Cui, X.; Hooper, G.J.; Lim, K.S.; Woodfield, T.B.F. Rational design, bio-functionalization and biological performance of hybrid additive manufactured titanium implants for orthopaedic applications: A review. J. Mech. Behav. Biomed. Mater. 2020, 105, 103671. [CrossRef] 
188. Karageorgiou, V.; Kaplan, D. Porosity of 3D biomaterial scaffolds and osteogenesis. Biomaterials 2005, 26, 5474-5491. [CrossRef]

189. Loeber, L.; Biamino, S.; Ackelid, U.; Sabbadini, S.; Epicoco, P.; Fino, P.; Eckert, J. Comparison of selective laser and electron beam melted titanium aluminides. In Proceedings of the 22nd Annual International Solid Freeform Fabrication Symposium-An Additive Manufacturing Conference, Austin, TX, USA, 8-10 August 2011.

190. Heinl, P.; Müller, L.; Körner, C.; Singer, R.F.; Müller, F.A. Cellular Ti-6Al-4V structures with interconnected macro porosity for bone implants fabricated by selective electron beam melting. Acta Biomater. 2008, 4, 1536-1544. [CrossRef]

191. Xue, W.; Krishna, B.V.; Bandyopadhyay, A.; Bose, S. Processing and biocompatibility evaluation of laser processed porous titanium. Acta Biomater. 2007, 3, 1007-1018. [CrossRef]

192. Pattanayak, D.K.; Fukuda, A.; Matsushita, T.; Takemoto, M.; Fujibayashi, S.; Sasaki, K.; Nishida, N.; Nakamura, T.; Kokubo, T. Bioactive Ti metal analogous to human cancellous bone: Fabrication by selective laser melting and chemical treatments. Acta Biomater. 2011, 7, 1398-1406. [CrossRef] [PubMed]

193. Armas, L.A.G.; Lappe, J.M.; Heaney, R.P. Chapter 19-Calcium, Bone Strength and Fractures. In Osteoporosis in Men, 2nd ed.; Academic Press: Waltham, MA, USA, 2010; ISBN 9780123746023.

194. Bundy, K.J. 3- Biomaterials and the chemical environment of the body. In Joint Replacement Technology; Woodhead Publishing: Cambridge, UK, 2008; ISBN 9781845692452.

195. Yuan, L.; Ding, S.; Wen, C. Additive manufacturing technology for porous metal implant applications and triple minimal surface structures: A review. Bioact. Mater. 2019, 4, 56-70. [CrossRef] [PubMed]

196. Ataee, A.; Li, Y.; Fraser, D.; Song, G.; Wen, C. Anisotropic Ti-6Al-4V gyroid scaffolds manufactured by electron beam melting (EBM) for bone implant applications. Mater. Des. 2018, 137, 345-354. [CrossRef]

197. Poumarat, G.; Squire, P. Comparison of mechanical properties of human, bovine bone and a new processed bone xenograft. Biomaterials 1993, 14, 337-340. [CrossRef]

198. Bagheri, A.; Buj-Corral, I.; Ferrer, M.; Pastor, M.M.; Roure, F. Determination of the elasticity modulus of 3D printed octet-truss structures for use in porous prosthesis implants. Materials 2018, 11, 2420. [CrossRef]

199. Moravej, M.; Mantovani, D. Biodegradable metals for cardiovascular stent application: Interests and new opportunities. Int. J. Mol. Sci. 2011, 12, 4250-4270. [CrossRef]

(C) 2020 by the authors. Licensee MDPI, Basel, Switzerland. This article is an open access article distributed under the terms and conditions of the Creative Commons Attribution (CC BY) license (http://creativecommons.org/licenses/by/4.0/). 